Brigham Young University Law School

BYU Law Digital Commons

Faculty Scholarship

$12-31-2015$

\title{
Pricing Disintermediation: Crowdfunding and Online Auction IPOs
}

A. Christine Hurt

BYU Law School, hurtc@law.byu.edu

Follow this and additional works at: https://digitalcommons.law.byu.edu/faculty_scholarship

Part of the Business Organizations Law Commons, Entrepreneurial and Small Business Operations Commons, and the Finance and Financial Management Commons

\section{Recommended Citation}

A. Christine Hurt, Pricing Disintermediation: Crowdfunding and Online Auction IPOs, 2015 ILL. L. ReV. 217.

This Article is brought to you for free and open access by BYU Law Digital Commons. It has been accepted for inclusion in Faculty Scholarship by an authorized administrator of BYU Law Digital Commons. For more information, please contact hunterlawlibrary@byu.edu. 


\section{PRICING DISINTERMEDIATION: CROWDFUNDING AND ONLINE AUCTION IPOS}

Christine Hurt*

Recently, the concept of crowdfunding has reignited a desire among both entrepreneurs and investors to harness technology to assist smaller issuers in the funding of their business ventures. Like the online auction IPO of the previous decade, equity crowdfunding promises both to disintermediate capital raising and democratize retail investing. In addition, crowdfunding could make capital raising more accessible to small issuers than any type of IPO or private offering. Until the passage of the Jumpstart Our Business Startups Act ("JOBS Act") in 2012, however, crowdfunding sites operated in a netherworld of uncertain regulation. In this crowdfunding Wild West, various types of entrepreneurs raised monies in various ways, some in obvious violation of the Federal Securities Acts.

The passage of Title III of the JOBS Act, the Capital Raising Online While Deterring Fraud and Unethical Non-Disclosure Act ("CROWDFUND" Act) seemed to bless the attempts of crowdfunding pioneers in the area of capital raising. The statutory language, however, does not exempt early entrants' efforts; instead, it provides a mechanism for future attempts to qualify for an exemption. The proposed Regulation Crowdfunding leaves little doubt that crowdfunding will not be easy: disclosure requirements, portal registration, and capital limitations are just a few of the costly burdens added to this would-be alternative. Even if crowdfunding may not be the optimal path for startups with an ultimate goal of a successful IPO, though, crowdfunding may be useful for other types of for-profit ventures. Regardless of the future of the SEC regulations, the legal charitable crowdfunding of donations will be unaffected and will continue to increase in popularity and acceptance. With the growth of charitable crowdfunding, for-profit social entrepreneurship may find equity crowdfunding both appealing and available as an attractive alterna-

* Rex J. \& Maureen E. Rawlinson Professor of Law, J. Reuben Clark Law School, Brigham Young University. The author would like to thank helpful assistance from Joan Heminway, Haskell Murray, Steven Bradford, and participants at the July 2013 Crowdfunding conference at the Leeds School of Business, University of Colorado-Boulder, participants at the May 2013 Law and Society Annual Conference, and workshop participants at BYU Law School. 
tive to private equity financing, which may be tempting but may also lead to mission drift and loss of founder control.

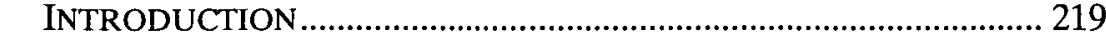

II. CROWDFUNDING AND THE PROMISE OF

DISINTERMEDIATION.................................................................. 222

A. Crowdsourcing and Crowdfunding .................................... 222

B. Disintermediation by the Crowd .......................................... 224

III. THE BIRTH AND DEATH OF THE ONLINE IPO............................. 2225

A. The Bookbuilding IPO .......................................................... 225

B. The Birth of the Online IPO Auction .................................... 227

C. The Death of the Online Auction IPO ................................... 231

IV. THE WILD WEST DAYS OF CROWDFUNDING .............................. 233

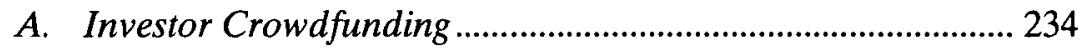

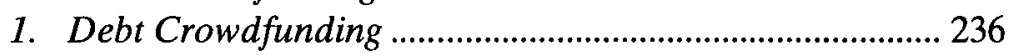

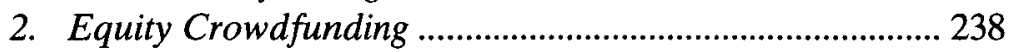

V. LEGAL EQUITY CROWDFUNDING UNDER THE JOBS ACT ........ 242

A. The CROWDFUND Act ..................................................... 243

B. Regulation Crowdfunding ...................................................... 246

C. The JOBS Act Enhances Other Capital-Raising Avenues..... 248

1. The IPO On-Ramp ......................................................... 248

2. Rule 506 and General Solicitation................................... 249

VI. THE UNCERTAIN FUTURE OF INVESTOR CROWDFUNDING........ 251

A. Equity Crowdfunding Is Doomed Because Fraud Will Be Rampant ............................................................................... 251

B. Equity Crowdfunding Is Doomed Because Section 4(6) Is Too Costly and Burdensome on Issuers and Portals ............. 252

C. Equity Crowdfunding Is Doomed Because It Will Be a Market of Lemons .................................................................. 254

D. Retail Equity Crowdfunding Is Doomed Because Issuers Will Choose Accredited Equity Crowdfunding under New Rule 506 ............................................................................... 255

E. Retail Equity Crowdfunding Is Doomed Because Funders Will Not Participate in Future Profits ..................................... 255

F. Retail Equity Crowdfunding Is Doomed Because the Financial Services Industry Will Avoid Crowdfunded

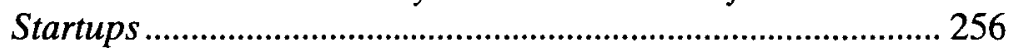

VII. EQUITY CROWDFUNDING FOR SOCIAL ENTERPRISE ................. 258

VIII. CONCLUSION ............................................................................... 260 


\section{INTRODUCTION}

Fifteen years ago, the explosion of the Internet promised to democratize the capital markets, increasing both access to capital for new companies and access to investments in initial public offerings to retail investors. One innovation born of this opportunity was the online auction initial public offering ("IPO"), ${ }^{1}$ an alternative to the traditional bookbuilding method of underwriting IPOs that allocates IPO shares to valued customers of the underwriters, often at a discount to market value. ${ }^{2}$ The promised magic of the online IPO, however, was never realized. ${ }^{3}$ Though several large investment banks were granted permission to host online IPOs through no-action letters by the Securities and Exchange Commission ("SEC") 4 and many created online auction platforms, only one investment bank, W.R. Hambrecht + Co., commercialized such a platform for public offerings of equity securities. ${ }^{5}$ Moreover, one of the largest IPOs of this millennium, the Google IPO, was characterized as an online auction IPO, ${ }^{6}$ but few others have followed in the wake of Google's shaky launch. The roughly twenty auction IPO issuers may have avoided Wall Street underpricing and preferential allocations, but they also forewent Wall Street salesmanship ${ }^{7}$ and analyst research. ${ }^{8}$ With a loss of less than one percent of IPOs to the auction IPO format, the death of the expensive bookbuilding method was much exaggerated.

1. See Christine Hurt, Moral Hazard and the Initial Public Offering, 26 CARDozo L. REV. 711, 769 (2005) ("The availability of online IPO auction mechanisms promise a much more democratic IPO process whereby the larger public has the opportunity to participate.").

2. See Sean J. Griffith, Spinning and Underpricing: A Legal and Economic Analysis of the Preferential Allocation of Shares in Initial Public Offerings, 69 BROOK. L. REV. 583, 594 (2004) ("By granting highly profitable IPO allocations to savvy business-people who well understand that nothing in this world is free, underwriters can expect real returns on their investment in goodwill.").

3. See Mark Lewis, Online IPO Revolution Postponed, FORBES (Mar. 14, 2001), http://www. forbes.com/2001/03/14/0314banks.html (reporting that Walter Cruttenden, CEO of E*Offering, had predicted that by 2002 , " $80 \%$ of IPOs would be completed online").

4. The first no-action letter issued by the SEC to an underwriter purporting to offer equity shares in an initial public auction was to Wit Capital in 1999, and it allowed online auctions in IPOs, though technically SEC rules concerning the timing of offers and sales of securities did not correspond with an ongoing bidding mechanism. See Wit Capital Corp., SEC No-Action Letter, [1999 Transfer Binder] Fed. Sec. L. Rep. (CCH) II 77,577 at 78,906 (July 14, 1999).

5. See About WR Hambrecht + Co., WR HAMBRECHT + CO., www.wrhambrecht.com/about (last visited Oct. 20, 2014).

6. See Op-Ed., Review \& Outlook: Google's Dutch Treat, Wall ST. J., May 3, 2004, at A20.

7. See Christine Hurt, What Google Can't Tell Us About Internet Auctions (And What It Can), 37 U. TOL. L. REV. 403, 428 (2006) [hereinafter Hurt, Google] ("Auction opponents criticized Google's confusing auction and managerial missteps for destroying much of the value that could have been captured in the IPO and depressing the price. Critics blamed Google both for alienating institutional investors and for scaring away retail investors."); see also Mark Calvey, IPO Rebel Defies Wall Street, S.F. BUS. TIMES, Jan. 30, 2005, http:/www.bizjournals.com/sanfrancisco/stories/2005/01/ 31/story2.html?page=all (quoting Thomas Weisel, CEO of Thomas Weisel Partners (one of Google's underwriters) as saying the Google auction was a failure because only two legitimate institutional investors participated in the instant auction).

8. See Christine Hurt, Initial Public Offerings and the Failed Promise of Disintermediation, 2 ENTREPRENEURIAL BUS. L.J.703, 735-37 (2008) [hereinafter Hurt, Disintermediation] (positing that issuers attempting to yield one hundred percent of market value $(X)$ instead of eighty-two percent of $X$ in a bookbuilding IPO instead yielded one hundred percent of $X$ less the added value of a Wall Street underwriter $(\mathrm{Z})$, and that $.82(\mathrm{X}-\mathrm{Z})$ is greater than $1(\mathrm{X})$ ). 
Recently, the concept of crowdfunding has reignited a desire among both entrepreneurs and investors to harness technology to assist smaller issuers in the funding of their business ventures. Like the online auction IPO, equity crowdfunding promises both to disintermediate capital raising and democratize retail investing. In addition, crowdfunding could make capital raising more accessible to small issuers than any type of IPO or private offering. Until the passage of the Jumpstart Our Business Startups Act ("JOBS Act") in 2012, ${ }^{9}$ however, crowdfunding sites operated in a netherworld of uncertain regulation. In this crowdfunding Wild West, various types of entrepreneurs raised monies in various ways, some in obvious violation of the Securities Act of 1933 (the "Securities Act"). Many of those raising funds were individuals or small groups of individuals, requesting funding for projects ranging from artistic endeavors to philanthropic causes to commercial inventions. Platforms emerged to offer templates and traffic, such as Kickstarter, RocketHub, and Indiegogo. Some fundraisers were registered not-for-profit corporations; some were registered corporate entities such as corporations or limited liability companies; most were individuals or unincorporated groups. Some fundraisers promised rewards or preordered products; some promised return of principal; some promised returns on principal; some promised nothing.

For entrepreneurs looking to raise startup capital, crowdfunding was attractive but dangerous. The riskiest incentive for crowdfunding entrepreneurs to offer funders was interest on principal or an equity stake - the two models most likely to raise the attention of the SEC as the offer or sale of securities without the benefit of registration. ${ }^{10}$ Though commercial ventures could offer funders a different incentive, such as early delivery of a proposed product, such a model necessarily limited the amount of funds that could be raised. Some portals, such as ProFounder, Prosper, and Lending Club, purported to give entrepreneurs an easy and legal way to crowdfund equity capital or interest-bearing loans; however, regulatory scrutiny caught up with those skirting the securities laws. ${ }^{11}$

The passage of Title III of the JOBS Act, the Capital Raising Online While Deterring Fraud and Unethical Non-Disclosure Act ("CROWDFUND Act") ${ }^{12}$ seemed to bless the attempts of crowdfunding pioneers in the area of capital raising, at least in theory. The statutory

9. Jumpstart Our Business Startups Act, Pub. L. No. 112-106, 126 Stat. 306 (2012). The JOBS Act is a package of legislation designed to spur economic growth through loosening regulations on capital formation by small businesses. The creative acronym points to the argument that most new jobs are created by new small businesses. See Spurring Job Growth, Through Capital Formation, Hearing Before the S. Comm. on Banking, Housing \& Urban Affairs, 112th Cong. 1 (2012) (statement of Timothy Rowe, CEO, Cambridge Innovation Center) [hereinafter Rowe Testimony] (citing statistics that for every job lost by firms six years old or older, firms less than six years old created three).

10. These types of returns constitute "securities" under Section 2(a)(1) of the Securities Act. 15 U.S.C. $\S 77(\mathrm{~b})$ (2012). See infra Section IV.A (detailing the securities laws implicated by the sale of "shares," "investment contracts," and "notes" without registration).

11. See infra Section IV.A (describing the fates of various investor crowdfunding sites).

12. CROWDFUND Act, Pub. L. No. 112-116, 126 Stat. $306 \S 301-305$ (2012) (codified as amended in scattered sections of 12 U.S.C. and 15 U.S.C.). 
language, however, does not exempt early entrants' efforts; instead, it merely provides a mechanism for future crowdfunding attempts to qualify for an exemption..$^{13}$ Even with proposed SEC rules nearing finalization $^{14}$ the question remains - which types of entrepreneurs and funding models will survive and thrive under a new crowdfunding regime? The statutory provisions of the JOBS Act leave little doubt that crowdfunding will not be easy: disclosure requirements, portal registration, and capital limitations are just a few of the details that may not be substantially alleviated by the SEC in regulations. ${ }^{15}$ The most optimistic commentators hope that crowdfunding eases access to capital markets for promising for-profit ventures, creating a new step in the life cycle of a startup: friends and family funding, crowdfunding, angel investing, venture capital ("VC"), and then IPO. On the other hand, critics predict that crowdfunding will go the way of the online auction, an unnecessarily complicated mechanism that stigmatizes those issuers who try to sidestep traditional Wall Street intermediaries.

Even if crowdfunding may not be the optimal path for startups with an ultimate goal of a successful IPO, crowdfunding may be useful for other types of for-profit ventures. Regardless of the future of the SEC regulations, the legal, charitable crowdfunding of donations will be unaffected and will continue to increase in popularity and acceptance. With the growth of charitable crowdfunding, for-profit social entrepreneurship may find equity crowdfunding both appealing and available. For-profit social entrepreneurs may be able to use the crowdfunding vehicle to brand themselves as prosocial, attracting individual and institutional cause investors who may operate outside of traditional capital markets and may look for intangible returns. Just as charitable crowdfunders rebut the conventional wisdom that donors expect tax deductibility, prosocial equity crowdfunders may rebut the conventional wisdom that early equity investors expect high returns or an exit mechanism. This avenue may be an attractive alternative to private equity financing, which may be tempting but may also lead to mission drift and loss of founder control. ${ }^{16}$

13. In fact, the mere passage of the Act exempting crowdfunding meeting the new requirements implicitly condemned existing investor crowdfunding. See JOBS Act Implementation: Hearing Before the H. Comm. on Small Bus., 113th Cong. 8 (2013) (statement of James J. Angel, Assoc. Prof., McDonough School of Business, Georgetown University) [hereinafter Angel Testimony] (describing how passage of the Act instantly signaled that crowdfunding was illegal until such time as the SEC adopted proposed rules, which experienced substantial delay).

14. See Crowdfunding, 78 Fed. Reg. 66,428 (proposed Nov. 5, 2013) (to be codified at 17 C.F.R. pts. 200, 227, 232, 239, 240, 249) [hereinafter Proposed Regulation Crowdfunding]. Comments on the proposed regulations were open for ninety days. As of this writing, the rules have not been amended or made final.

15. See infra Section $\mathrm{V}$ (describing the restrictions in both the statute and the regulations, and the criticisms of them).

16. See J. Haskell Murray, Choose Your Own Master: Social Enterprise, Certifications and Bene. fit Corporation Statutes, 2 AM. U. BUS. L. REV. 1, 22-24 (2012) (discussing the potential of benefit corporation statutes to remedy the plight of social entrepreneurs who wish to take on outside capital but not at the cost of mission drift); Antony Page \& Robert A. Katz, Freezing Out Ben \& Jerry: Corporate 
Part II of this Article will briefly describe the allure and origins of internet crowdfunding. Part III will chronicle the history and current state of online auction IPOs. Part IV will provide a background of the legal crowdfunding landscape prior to passage of the JOBS Act, drawing on the scholarship of others who have been drawing the parameters of future investor crowdfunding under the JOBS Act and early glimpses of $S E C$ regulation implementing those crowdfunding provisions. Part V discusses the legal avenues for crowdfunding under the JOBS Act. Part VI will explore theories that investor crowdfunding may fail, either because of regulatory cost, capital structure, or negative signaling to the market. This Part will also discuss how, by liberalizing other private placement safe harbors, Congress may have made crowdfunding less necessary or attractive for some companies. In addition, the predicted failure of equity crowdfunding will be compared to the realized failure of the online auction IPO format. Finally, Part VII will propose that the success of donor charitable crowdfunding and its implications for prosocial enterprises and "low-profit" corporations.

\section{CROWDFUNDING AND THE PROMISE OF DISINTERMEDIATION}

\section{A. Crowdsourcing and Crowdfunding}

Though the SEC did not issue crowdfunding regulations until 2013, crowdfunding by that time had already become a well-known avenue for funding projects ranging from musical recordings, theater performances, theater preservation, dance performances, documentaries, and films to new products, video games, and phone/tablet applications. Crowdfunding is a familiar concept within a larger umbrella of crowdsourcing, which is an open call to the public to provide information or monies for a cause or project. At its most general level, pledge drives for public radio stations ${ }^{17}$ and charity telethons ${ }^{18}$ are time-honored examples of crowdsourcing for funds over radio or television, but the advent of global connectivity via the Internet has fueled a revolution for crowdsourcing not just funds, but information and political support. Endeavors such as Wikipedia are ex-

Law and the Sale of a Social Enterprise Icon, 35 VT. L. REV. 211, 211-12 (2010) (chronicling the sale of Ben \& Jerry's ice cream company).

17. See JaCk W. Mrtchell, Listener Supported: The Culture and History of Public RADIO 165-66 (2005) (relating the rise of donation drives for public radio stations to the Reagan budget cuts of the early 1980 s).

18. See David Johnston \& Jennifer Leonard, TV Charities: Let the Giver Beware, L.A. TIMES, Jan. 20, 1985, http://articles.latimes.com/1985-01-20/entertainment/ca-10627_1_tv-charity (chronicling the rise of telethons from the first hosted by United Cerebral Palsy in 1951 , which raised $\$ 276,408$, to 1985 , in which seven national and more than fifty regional or local telethons were broadcast). From 1972 to 1983 , the Democratic National Committee hosted several national telethons to raise campaign contributions. Democrats Say "Jamming" by GOP Hurt Telethon, N.Y. TIMES, May 30, 1983, http:// www.nytimes.com/1983/05/30/us/democrats-say-jamming-by-gop-hurt-telethon.html (reporting that ninety percent of calls in the first few hours were "hostile" calls from Republican party members); John W. Elwood \& Robert Spitzer, The Democratic National Telethons: Their Successes and Failures, $41 \mathrm{~J}$. OF POL. 828, 830 (1979) (listing net profits of four telethons in the 1970s as ranging from a high of $\$ 1.9$ million in 1972 to a low of $\$ 909,771$ in 1975). 
amples of crowdsourcing of information. ${ }^{19}$ MoveOn.org reinvented political fundraising by using the Internet to mobilize younger voters and their dollars. ${ }^{20}$ Change.org crowdsources signatures and attention for internet petitions sent to corporations, politicians, and others. ${ }^{21}$ Disaster websites asking for donations for groups, such as One Fund Boston, or for particular victims of the Boston Marathon bombing tragedy, are crowdsourcing compensation for tort victims. ${ }^{22}$ Donations by mobile phone texting have also changed disaster relief. ${ }^{23}$ DonorsChoose lets potential donors choose among ideas from public school teachers near and far. ${ }^{24}$ Small donations from many individuals source the success of these projects. ${ }^{25}$

But online platforms do not solely have to be used as a way to minimize transaction costs to solicit donations for traditional causes and charities. Razoo ${ }^{26}$ and StartSomeGood ${ }^{27}$ are websites that focus on newer or smaller nonprofits and social entrepreneurs, many of which would not be able to raise funds without an internet platform. Soon, website portals such as Kickstarter, ${ }^{28}$ RocketHub, ${ }^{29}$ and IndieGoGo $0^{30}$ emerged to provide

19. See Eric Goldman, Wikipedia's Labor Squeeze and its Consequences, 8 J. ON TELECOMM. \& HIGH TECH. L. 157, 158 (2010) ("The Internet allows geographically dispersed individuals to voluntarily contribute their time and expertise towards socially productive tasks. Wikipedia is a shining example of this phenomenon."); Beth Simone Noveck, Wikipedia and the Future of Legal Education, $57 \mathrm{~J}$. LEGAL EDUC. 3, 4 (2007) (explaining how "wikis" are used and the collaborative editing software on which wikis are based).

20. What is Move On?, MOVEON.ORG, http:/front.moveon.org/about/\#.VAiS8GSWx74 (last visited Oct. 20, 2014). See Nathaniel J. Gleicher, Moneybombs and Democratic Participation: Regulating Fundraising by Online Intermediaries, 70 MD. L. REV. 750, 766-67 (2011) (describing the creation of MoveOn.org in 1998, as well as the creation of other online independent fundraising groups such as Freedom Works).

21. About Change.org, ChANGE.ORG, https://www.change.org/about (last visited Oct. 20, 2014). See Nicholas D. Kristof, After Recess: Change the World, N.Y. TIMES, Feb. 5, 2012, http://www. nytimes.com/2012/02/05/opinion/sunday/kristof-after-recess-change-the-world.html (describing successful Change.org petitions by children and other average individuals that caused large corporations to change policies). Causes.com, run by a for-profit corporation, also hosts petitions and allows users to raise money for causes. CAUSES.COM, https://www.causes.com (last visited Oct. 20, 2014).

22. See Christine Hurt, One Fund Boston, Torts and Social Capital, Conglomerate (Apr. 23, 2013), http://www.theconglomerate.org/2013/04/one-fund-boston-torts-and-social-capital.html.

23. See Suzanne Martindale \& Gail Hillebrand, Pay at Your Own Risk? How to Make Every Way to Pay Safe for Mobile Payments, 27 BANKING \& FIN. L. REV. 265, 270 (recounting how the American Red Cross raised $\$ 5$ million in forty-eight hours through SMS (short message service) mobile phone texts after the 2010 hurricane in Haiti).

24. See Ryan Mac, DonorsChoose's Charles Best: Pioneering Citizen Philanthropy, FORBES (Sept. 18, 2012), http:/www.forbes.com/sites/ryanmad/2012/09/18/donorschooses-charles-bestpioneering-citizen-philanthropy/ (describing the creation of DonorsChoose.org by a young history teacher, who can now count Oprah Winfrey and Stephen Colbert among his board members).

25. Other websites that offer fundraising platforms for soliciting donations are Fundly.com, GoGetFunding.com, and Crowdrise.com. FuNDLY.COM, https://fundly.com (last visited Oct. 20, 2014); GoGETFUNDING.COM, http://gogetfunding.com (last visited Oct. 20, 2014); CROWDRISE.COM, https:// www.crowdrise.com/ (last visited Oct. 20,2014). CauseWish.com is a website for soliciting donations for personal medical costs. CAUSEWISH.COM, http://causewish.com (last visited Oct. 20, 2014).

26. RAzoo, www.razoo.com (last visited Oct. 20, 2014). Razoo also allows individuals to fundraise for personal causes. Why Individuals Love Razoo, RAZOo, www.razoo.com/p/for_individuals (last visited Oct. 20,2014).

27. STARTSOMEGOOD, www.startsomegood.com (last visited Oct. 20, 2014). StartSomeGood divides causes into eleven categories, ranging from Art \& Culture to Human Rights. Id.

28. KICKSTARTER, www.kickstarter.com (last visited Oct. 20, 2014). 
platforms for individuals and groups to ask the public to fund various types of projects, from artistic to altruistic to technology-related projects. According to statistics updated daily on its website, Kickstarter, the leading crowdfunding platform, has featured 169,845 projects, of which $40.06 \%$, or 68,048 , have been successfully funded, as of August $2014 .^{31}$ Over 6.8 million "backers" have pledged to projects, and over 2 million are repeat backers. ${ }^{32}$ In all, the projects have attracted $17,166,433$ pledges since $2009 .{ }^{33}$ Over all platforms, an estimated $\$ 3$ billion was crowdfunded in $2012 . .^{34}$

\section{B. Disintermediation by the Crowd}

Crowdfunding has the potential to disrupt early stage equity investing in the same way that auction IPOs promised to subvert the bookbuilding paradigm. In traditional IPOs, underwriters have significant control over pricing, allocation, and underwriting fees. The auction IPO attempted to reduce costs and democratize the distribution to retail investors. Likewise, the angel investing industry and venture capital industry have their own inherent biases. Early round investing depends greatly on networks and geography; $;^{35}$ almost all startup companies with VC funding were founded by men and led by men. ${ }^{36}$ Crowdfunding can eliminate these biases and democratize both the investing side, allowing retail investors to participate in early stage investing, and also the entrepreneur side, giving access to capital to a wider range of founders..$^{37}$ Just as auc-

\footnotetext{
29. ROCKETHUB, www.rockethub.com (last visited Oct. 20, 2014).

30. INDIEGOGO, www.indiegogo.com (last visited Oct. 20, 2014). 2014).

31. Stats, KICKSTARTER, https://www.kickstarter.com/help/stats?ref=footer (last visited Oct. 20 ,

32. Id.

3p. Id.

34. See David Zvilichovsky et al., Playing Both Sides of the Market: Success and Reciprocity on Crowdfunding Platforms 2 (Social Science Research Network, Working Paper No. 2304101, 2013) available at http://ssrn.com/abstract=2304101 (2013); Anita Hamilton, How to Crowdfund Your Creative Project, TIME (Oct. 22, 2012), http://business.time.com/2012/10/22/how-to-crowdfund-yourcreative-project/slide/introduction/ (citing estimates that $\$ 3$ billion would be crowdfunded in 2012, twice the $\$ 1.5$ billion raised in 2011 ).

35. See Rowe Testimony, supra note 9 (testifying as to the uneven distribution of risk capital across regions of the United States); Equity Finance: Catalyst for Small Business Growth Hearing Before the Subcomm. on the Economic Growth, Tax, and Capital Access of the H. Comm. on Small Bus., 112th Cong. (2012) (statement of Jason W. Best, Cofounder, Startup Exemption) (giving as examples entrepreneurs in Natchitoches, Louisiana or Arnold, Nebraska who may not have access to angel investors but have great ideas); Ethan Mollick, Swept Away By the Crowd? Crowdfunding, Venture Cap. ital, and the Selection of Entrepreneurs 8 (Social Science Research Network, Working Paper 2239204, 2013), available at http://www.ssrn.com/abstract $=2239204$ [hereinafter Mollick, Selection] (citing studies that show that the average distance between a venture capital firm and an entrepreneur is seventy miles).

36. See Mollick, Selection, supra note 35 (citing evidence that $6 \%$ of venture capital funding goes to companies with a female $\mathrm{CEO}$, and only $1.3 \%$ to companies with a female founder or cofounder, compared with a population of companies in which females constitute $40 \%$ of business owners).

37. See Ajay Agrawal et al., The Geography of Crowdfunding, (Nat'l Bureau of Econ. Research, Working Paper No. 16820, 2011) (studying the Amsterdam portal Sellaband and noting that the average distance between the crowdfunder and the project owner was 3000 miles); Mollick, Selection, supra note 35 , at 16 (noting in the author's crowdfunding sample, gender was not predictive).
} 
tion IPOs were an alternative to pricey investment banks, crowdfunding could be an alternative to angel investing and venture capital investing that can cost founders managerial control. Before focusing attention on the regulatory concerns related to crowdfunding, a brief history of the online auction IPO may be instructive.

\section{THE BIRTH AND DEATH OF THE ONLINE IPO}

\section{A. The Bookbuilding IPO}

Corporations (and other types of for-profit entities) seeking equity capital beyond the capital of existing shareholders have few options for legal capital-raising. Selling equity (and debt) securities is highly regulated by the SEC, and the Securities Act provides a costly and complicated structure for selling securities to the public. SEC regulations provide various avenues for privately placing securities with investors in nonpublic offerings, but there is only one pathway to harness the capital-raising potential of an initial public offering: share registration under the Securities Act. IPOs raise capital for the issuer and create liquidity for early shareholders, but they also entail a lengthy and expensive registration process and lock in the issuer to mandatory periodic disclosures with the SEC. ${ }^{38}$ The registration process also submits the issuer to the antifraud provisions of the Securities Act and the Securities Exchange Act of 1934 (the "Exchange Act").

Another aspect of the IPO process that increases the cost of capital raising is the distribution method employed by the underwriters of the offering. In the United States, the near-exclusive method of distributing shares in an IPO is the bookbuilding method. In this method, the underwriter seeks indications of interest from large, institutional investors and other wealthy investors concerning the number of shares that an investor might purchase at certain prices. This information gathering happens during the registration waiting period, often at road shows or at individual face-to-face meetings. Though regulations limit the distribution of written information that issuers may provide investors during the registration process, oral communications are unregulated, giving increased information to investors with personal access to the issuer or underwriters. As the registration of the shares becomes effective, the underwriter allocates IPO shares to institutional investors, regular individual customers, persons on the issuer's "friends and family list," and other individuals at the discretion of the underwriter..$^{39}$ Through this bookbuilding process, the vast majority of the original IPO shares will be distributed to

38. See Michael D. Guttentag, Patching a Hole in the JOBS Act: How and Why to Rewrite the Rules that Require Firms to Make Periodic Disclosures, 88 IND. L.J. 151, 181-84 (2013) (discussing the negative repercussions of costly disclosure for all firms with registered securities).

39. See Therese H. Maynard, Spinning in a Hot IPO-Breach of Fiduciary Duty or Business as Usual?, 43 WM. \& MARY L. REV. 2023, 2031 (2002) ("In general, the lead underwriter's decision as to how to allocate the shares of an IPO is not subject to substantive regulation under the terms of either the 1933 or 1934 Acts."). 
known investors through the underwriters. ${ }^{40}$ Retail investors, then, purchase the shares that these recipients sell in the first few hours of the IPO and the small number of shares that were not allocated..$^{41}$

In "hot" IPO markets, underwriters may have an incentive to "underprice" IPO shares, knowing that allocating underpriced shares to its customers has the effect of giving investors prepackaged profit. ${ }^{42}$ IPO recipients can then sell these underpriced shares at market prices on the first day, pocketing the difference. ${ }^{43}$ Underwriters may use this ability to strengthen relationships with potential, new, or favored customers. ${ }^{44}$ Many have suggested more legitimate reasons for underpricingmarketing strategy, ${ }^{45}$ lowering liability risk ${ }^{46}$ compensating for underwriter liability risk ${ }^{47}$ assisting a firm-commitment offering ${ }^{48}$ compensating institutional investors for price discovery, ${ }^{49}$ placing shares with long

40. See Reena Aggarwal et al., Institutional Allocation in Initial Public Offerings: Empirical Evidence, 57 J. OF FIN. 1421, 1430 (2002) (stating that institutional investors receive approximately seventy-five percent of all original IPO shares).

41. See Beatrice Boehmer et al., Do Institutions Receive Favorable Allocations in IPOs with Better Long Run Returns?, 41 J. OF FIN. \& QUANTITATIVE ANALYSIS 809, 814 (2006) (stating that in their sample, seventy-nine percent of the shares in the IPOs were allocated by the underwriter).

42. See Francois Derrien \& Kent L. Womack, Auctions vs. Bookbuilding and the Control of Underpricing in Hot IPO Markets, 16 REV. OF FIN. STUD. 31, 31 (2013) (concluding that in hot markets, underpricing of IPO shares can be "double-digit" or "triple-digit"); Jay Ritter \& Ivo Welch, A Review of IPO Activity, Pricing, and Allocations, 57 J. FIN. 1795, 1816 (2002) (stating that between 1980-1997, IPO shares had offering prices fifty percent higher than the share prices of comparable publicly-held companies with similar fundamentals).

43. See In re eBay, Inc. S'holders Litig., No. C.A. 19988-NC, 2004 WL 253521, at *1 (Del. Ch. Jan. 23, 2004) ("For these services, eBay has paid Goldman Sachs over \$8 million. During this same time period, Goldman Sachs 'rewarded' the individual defendants by allocating to them thousands of IPO shares, managed by Goldman Sachs, at the initial offering price. Because the IPO market during this particular period of time was extremely active, prices of initial stock offerings often doubled or tripled in a single day. Investors who were well connected, either to Goldman Sachs or to similarly situated investment banks serving as IPO underwriters, were able to flip these investments into instant profit by selling the equities in a few days or even in a few hours after they were initially purchased.").

44. See id. The eBay case interestingly involved shareholders alleging a breach of fiduciary duty against officers of a Goldman Sachs client that accepted IPO shares that were instantly profitable because the profit belonged to the corporation. Id. Other lawsuits attempting to litigate underwriter allocations were largely unsuccessful, though one class action lawsuit alleging series of various IPO abuses was defended vigorously for a decade before settling. In re Initial Pub. Offering Sec. Litig., 241 F. Supp. 2d 281, 293, 295-98 (S.D.N.Y. 2003) (partial denial of motion to dismiss); 671 F. Supp. 2d 467, 470 (S.D.N.Y. 2009) (preliminary approval of settlement).

45. See HERSH SHEFRIN, BEYOND GREED AND FEAR: UNDERSTANDING BEHAVIORAL FINANCE AND THE PSYCHOLOGY OF INVESTING 248 (2000) (hypothesizing that investment banks underprice issues to create demand for the purpose of motivating investors to form a "bandwagon").

46. See Janet Cooper Alexander, The Lawsuit Avoidance Theory of Why Initial Public Offerings Are Underpriced, 41 UCLA L. REV. 17, 24-26 (arguing that because securities fraud lawsuits require evidence of price drops and because damages are calculated based on that drop that underpricing mitigates both litigation risk and liability amounts).

47. See id. at 47 .

48. But see Ritter \& Welch, supra note 42, at 1807 (providing the counterargument that this theory is weak because underpricing is more severe in hot IPO markets when shares are easiest to sell).

49. See Ann E. Sherman \& Sheridan Titman, Building the IPO Order Book: Underpricing and Participation Limits with Costly Information, 65 J. FIN. ECON. 3, 4, 20 (2002); see also Ritter \& Welch, supra note 42, at 1805. 
term investors ${ }^{50}$ - but allocation abuses during hot IPO markets have been well-documented.

In the last hot IPO market in the late 1990s, underpricing happened frequently $^{51}$ and spurred a sentiment that issuers were leaving large amounts of capital on the table that was enriching intermediaries, ${ }^{52}$ but not issuers' coffers. ${ }^{53}$ One way to avoid underpricing would be to avoid the bookbuilding process by creating an online auction.

\section{B. The Birth of the Online IPO Auction}

If the primary justifications of IPO underpricing are information discovery and an effective distribution, then technology promised a cheaper solution than the bookbuilding process. An online IPO auction, used in other countries to some success, ${ }^{54}$ seemed like a revolution for the retail investor. In the purest form of online auction, the underwriter has little to no discretion in determining either the price of the IPO shares or the recipients of the distribution. The resulting offering price is the highest price at which all shares are sold, reflecting full demand for the IPO shares. Once the initial shares are sold, then secondary trading takes place on an exchange, such as the New York Stock Exchange ("NYSE") or the NASDAQ. Because the auction captured the highest price at which bidders offered to purchase the shares, the share price should not rise appreciably in the first few days. The result should be that issuers raise more capital in an online auction IPO than in a bookbuilding IPO. Assuming average underpricing of eighteen percent, ${ }^{55}$ theoretically an online auction IPO should yield an issuer $\$ 100$ million for the same offering in which a bookbuilding IPO would generate $\$ 82$ million.

In 1999 and 2000, multiple investment banks applied and received permission from the SEC to use Internet auctions for the distribution of

50. See A.C. Pritchard, Revisiting "Truth in Securities" Revisited: Abolishing IPOs and Harnessing Private Markets in the Public Good, 36 SEATTLE U. L. REV. 999, 1014 (2013).

51. See, e.g., Debra Baker, Who Wants to Be a Millionaire?, 86 A.B.A. J. 36, 36-37 (2000) (reporting that VA Linux Systems, Inc. stock was priced at $\$ 30$ per share, then closed on the first day of trading at more than $\$ 239$ per share); Devra Vrana, Califormia Dealin': In Both Price and Volume, IP. Os End 1999 with a Bang, L.A. TIMES, Dec. 27, 1999, http://articles.latimes.com/1999/dec/27/ business/fi-47884 (reporting that IPO shares in 1999 jumped an average of sixty-seven percent on the first day, and for California firms, the average first-day pop was ninety-eight percent).

52. See John C. Coffee, Jr., The IPO Allocation Probe: Who is the Victim, N.Y. L.J., Jan. 18, 2001 , at 5 (describing as dysfunctional an IPO system that sees up to seventy-five percent of the market value of the IPO shares going to either underwriters or institutional investors and not the issuer).

53. Generally, IPO shares do not do well over the first few years of trading, but underpriced IPO shares do even worse, contributing to a theory that issuers lost much-needed capital due to underpricing. See Rajesh K. Aggarwal et al., Strategic IPO Underpricing, Information Momentum, and Lockup Expiration Selling, 66 J. FIN. ECON. 105, 106 (2002); Alexander P. Ljungqvist et al., Hot Markets, Investor Sentiment, and IPO Pricing, 79 J. BuS. 1667, 1690 (2006) (showing that companies with first-day returns over sixty percent have the worst one-year returns of all issuers in the same year); Ritter \& Welch, supra note 42, at 1817 (concluding that IPO shares have negative three year returns and perform $23.4 \%$ worse than the average market portfolio over the same time period).

54. Hurt, Google, supra note 7, at 408-09.

55. See Ritter \& Welch, supra note 42 , at 1795. 
IPO shares in online auctions. ${ }^{56}$ These no-action letters were necessary because in an online auction, both the bidders and the issuer would need to be bound to the submitted bids before the price of the shares was set by the auction mechanism; in a registered offering under the Securities Act, no offers to purchase or sell may be made or accepted until the registration statement, including the set price, is declared effective. ${ }^{57}$ In an online auction, technology would, in effect, disintermediate IPOs, shifting both pricing and allocation power from underwriters to the issuer. Not only would issuers be able to sell their shares at a higher price, but the process would be democratized. Retail investors would be able to purchase at the market price ${ }^{58}$ not at a bandwagon price created by underpricing. By January 2000, "about a dozen" investment firms had created online systems to distribute IPOs and thirty-eight percent of all IPOs in the last half of 1999 had an online component combined with a traditional bookbuilding IPO. ${ }^{59}$ Three full-fledged online IPOs were also conducted in 1999.60

Even so, the second half of 2000 signaled a cooling of the IPO market. The general reluctance of Wall Street to embrace the online IPO, combined with the decline of the U.S. economy, did not encourage the fledgling online IPO industry. Only one investment bank commercialized and maintained an online IPO auction platform: W.R. Hambrecht $+\mathrm{Co}^{61}$

56. See Wit Capital Corp., SEC No-Action Letter, 1999 WL 49854 (July 14, 1999) [hereinafter Wit Capital, 1999 Letter]; WR Hambrecht + Co., SEC No-Action Letter, 2000 WL 987735 (July 12, 2000) (approving online auctions for distribution of registered debt securities); Bear, Stearns \& Co., Inc., SEC No-Action Letter, 2000 WL 1013584 (July 20, 2000) (describing Bear, Stearns' Dutch Auction internet Syndication System ("DAiSS") for registered debt securities); Wit Capital Corp., SEC No-Action Letter, 2000 WL 1013585 (July 20, 2000) [hereinafter Wit Capital, 2000 Letter] (stating the auction will be used for follow-on, secondary, and combination offerings).

57. The Wit Capital letters described various ways to fine-tune the online auction, including giving bidders a range of prices approved by the SEC, then accepting conditional bids within that range. If not enough customers bid for shares at even the minimum price then the minimum price would be the share price and the issuer would sell all the shares to the underwriter at the price under a firm commitment underwriting. If bids at the share price exceeded the number of shares available, the issuer would allocate the shares to the bidders based strictly on the highest price bid by the bidder and the time of the bid. See Wit Capital, 2000 Letter, supra note 56, at *7-9. The 1999 Wit Capital Letter reserved the right of the issuer to require the underwriter to set aside "a specified number of shares in an offering for certain categories of employees or customers of the issuer or other person with an affinity relationship with the issuer." See Wit Capital, 1999 Letter, supra note 56, at *12.

58. See Steven Davidoff Solomon, After Years Without Change, Cracks Appear in I.P.O. Process, N.Y. TIMES DEALBOOK (June 15, 2011), http://dealbook.nytimes.com/2011/06/14/after-years-withoutchange-cracks-appear-in-i-p-o-process/ (noting that one advantage to the auction model is "[i]t brings retail investors back into the process because they can freely bid on issues" instead of subsidizing firstday gains).

59. See Laura S. Unger, Commissioner, SEC, Technology and Regulation: The Road Ahead, Address at the San Diego Securities Institute (Jan. 27, 2000), available at http://www.sec.gov/ news/speech/spch343.htm.

60. See Superior Results for Companies We Are Proud to Call Our Clients, WR HaMBRECHT + Co., www.wrhambrecht.com/clients (last visited Oct. 20, 2014).

61. Hambrecht + Co. was launched in $\mathbf{1 9 9 8}$ by Bill Hambrecht, a former investment banker at his own firm, Hambrecht + Quist. See Joe Nocera, Open and Fair: Why Wall St. Hates Auctions, N.Y. TIMES, Mar. 18, 2006, http://query.nytimes.com/gst/fullpage.html?res=990DE0D91E31F93BA25750 C0A9609C8B63 (quoting Hambrecht as saying that when he started auctions at the age of sixty-two, "I honestly thought that the abuses in the I.P.O. market were becoming so obvious that other firms would follow us"); see also Christian Berthelsen, Investment Banker Fights the System: Plan for Cutting 
In the fourteen years since 2000 , Hambrecht has hosted a mere twenty online IPOs. ${ }^{62}$

TABLE 1

\begin{tabular}{|c|c|c|c|c|c|}
\hline Issuer Name & $\begin{array}{c}\text { Date of } \\
\text { IPO }\end{array}$ & $\begin{array}{c}\text { Size of Offer- } \\
\text { ing }\end{array}$ & $\begin{array}{c}\text { Offering } \\
\text { Price }\end{array}$ & $\begin{array}{c}\text { Closing } \\
\text { Price }\end{array}$ & $\begin{array}{c}\text { Percent } \\
\text { Change }\end{array}$ \\
\hline $\begin{array}{c}\text { Truett-Hurst, } \\
\text { Inc. }\end{array}$ & $6 / 19 / 2013$ & $\$ 16,200,000$ & $\$ 6.00$ & $\$ 5.80$ & -3.333 \\
\hline $\begin{array}{c}\text { Rackspace } \\
\text { Hosting, Inc. }\end{array}$ & $8 / 08 / 2008$ & $\$ 187,500,000$ & $\$ 12.50$ & $\$ 10.01$ & -19.920 \\
\hline NetSuite Inc. & $12 / 20 / 2007$ & $\$ 161,200,000$ & $\$ 26.00$ & $\$ 35.50$ & 36.538 \\
\hline $\begin{array}{c}\text { Clean Energy } \\
\text { Fuels Corp. }\end{array}$ & $5 / 25 / 2007$ & $\$ 120,000,000$ & $\$ 12.00$ & $\$ 12.04$ & 0.333 \\
\hline $\begin{array}{c}\text { Interactive Bro- } \\
\text { kers Group, Inc. }\end{array}$ & $5 / 4 / 2007$ & $\$ 1,200,400,000$ & $\$ 30.01$ & $\$ 31.30$ & 4.298 \\
\hline FortuNet, Inc. & $1 / 31 / 2006$ & $\$ 22,500,000$ & $\$ 9.00$ & $\$ 9.05$ & 0.555 \\
\hline Traffic.com, Inc. & $1 / 25 / 2006$ & $\$ 78,600,000$ & $\$ 12.00$ & $\$ 12.01$ & 0.083 \\
\hline $\begin{array}{c}\text { Dover Saddlery, } \\
\text { Inc. }\end{array}$ & $11 / 17 / 2005$ & $\$ 27,500,000$ & $\$ 10.00$ & $\$ 10.25$ & 2.500 \\
\hline $\begin{array}{c}\text { Avalon Pharma- } \\
\text { ceuticals, Inc. }\end{array}$ & $9 / 28 / 2005$ & $\$ 28,875,000$ & $\$ 10.50$ & $\$ 9.49$ & -9.619 \\
\hline CryoCor, Inc. & $7 / 14 / 2005$ & $\$ 40,799,990$ & $\$ 11.00$ & $\$ 10.87$ & -1.181 \\
\hline $\begin{array}{c}\text { Morningstar, } \\
\text { Inc. }\end{array}$ & $5 / 2 / 2005$ & $\$ 140,831,250$ & $\$ 18.50$ & $\$ 20.05$ & 8.378 \\
\hline $\begin{array}{c}\text { Bofl Holding, } \\
\text { Inc. }\end{array}$ & $3 / 15 / 2005$ & $\$ 35,100,001$ & $\$ 11.50$ & $\$ 11.50$ & 0.000 \\
\hline Google Inc. & $8 / 18 / 2004$ & $\$ 1,666,429,400$ & $\$ 85.00$ & $\$ 100.34$ & 18.047 \\
\hline
\end{tabular}

IPO Conflicts Gets Attention, but Wall Street Dubious, S.F. CHRON., Sept. 22, 2002, http:/www.sfgate. com/business/article/Investment-banker-fights-the-system-Plan-for-2794048.php(describing Open IPO as "an alternative open-bidding process modeled on Dutch flower auctions to eliminate secretive IPO pricing strategies and what many experts consider allocation favoritism").

62. Superior Results for Companies We Are Proud to Call Our Clients, WR HamBrecht + Co., https://www.wrhambrecht.com/clients/ (last visited Oct. 20, 2014). This number overstates the case somewhat in that it includes the Google IPO, which was actually not hosted by Hambrecht, but by Morgan Stanley. Paul R. La Monica, Google Sets \$2.7 Billion IPO, CNN MoNeY (Apr. 30, 2004), http://money.cnn.com/2004/04/29/technology/google/.

63. Truett-Hurst, Inc., Registration Statement (Form S-1) (Mar. 11, 2013), available at http:// www.nasdaq.com/markets/ipos/filing.ashx?filingid=8744846. According to Truett-Hurst, Inc.'s Form S1, William R. Hambrecht is a director of Truett-Hurst and a major investor through Hambrecht Wine Group, L.P. Id. In addition, Truett-Hurst leases land and buildings from Hambrecht Wine Group as well as vineyards from Hambrecht Trust. Id. The Truett-Hurst IPO was criticized for raising only $\$ 14$ million in capital, though costing over $\$ 2$ million in fees. See Paul Franson, Truett Hurst Goes Public at Reduced Value, WINES AND VINES (June 26, 2013), http://www.winesandvines.com/template.cfm? section $=$ news\&content $=118483$. 


\begin{tabular}{|c|c|c|c|c|c|}
\hline $\begin{array}{c}\text { New River } \\
\text { Pharmaceuticals, } \\
\text { Inc. }\end{array}$ & $8 / 5 / 2004$ & $\$ 33,600,000$ & $\$ 8.00$ & $\$ 7.50$ & -6.250 \\
\hline $\begin{array}{c}\text { Genitope } \\
\text { Corporation }\end{array}$ & $10 / 30 / 2003$ & $\$ 33,300,000$ & $\$ 9.00$ & $\$ 10.00$ & -11.111 \\
\hline $\begin{array}{c}\text { RedEnvelope, } \\
\text { Inc. }\end{array}$ & $9 / 25 / 2003$ & $\$ 30,800,000$ & $\$ 14.00$ & $\$ 14.55$ & 3.928 \\
\hline Overstock.com & $5 / 29 / 2002$ & $\$ 39,000,000$ & $\$ 13.00$ & $\$ 13.03$ & 0.231 \\
\hline Briazz, Inc. & $5 / 2 / 2001$ & $\$ 16,000,000$ & $\$ 8.00$ & $\$ 8.03$ & 0.375 \\
\hline $\begin{array}{c}\text { Peet's Coffee } \\
\& \text { Tea }\end{array}$ & $1 / 25 / 2001$ & $\$ 26,400,000$ & $\$ 8.00$ & $\$ 9.38$ & 17.250 \\
\hline Nogatech, Inc. & $5 / 17 / 2000$ & $\$ 42,000,000$ & $\$ 12.00$ & $\$ 9.41$ & -21.583 \\
\hline Andover.net & $12 / 8 / 1999$ & $\$ 82,800,000$ & $\$ 18.00$ & $\$ 63.38$ & 252.111 \\
\hline Salon.com & $6 / 22 / 1999$ & $\$ 27,300,000$ & $\$ 10.50$ & $\$ 10.00$ & -5.000 \\
\hline Ravenswood & $4 / 9 / 1999$ & $\$ 11,550,000$ & $\$ 10.50$ & $\$ 10.88$ & 3.600 \\
\hline
\end{tabular}

Though very few companies have chosen the online auction route to IPO ${ }^{64}$ the auction mechanism has been successful in reducing the underpricing phenomenon of the average bookbuilding IPO. Some commentators point to the average first-day pop of all twenty-three auction IPOs and conclude that the auction does not significantly reduce underpricing. ${ }^{65}$ This set of issuers, however, contains one outlier IPO, Andover.net, which had a $252.08 \%$ first-day share price increase in $1999 .{ }^{66}$ Omitting that observation yields an average first-day increase among auction IPOs of $.725 \%{ }^{67}$ If the Google auction, which was run by Morgan Stanley, is omitted, the average first-day pop is $-.01 \%{ }^{68}$ The median first-day pop of all twenty-three auctions is $.333 \%{ }^{69}$ If the goal of the online auction is to

64. According to Professor Jay Ritter, 1568 operating companies went public in the United States between January 1, 2000, and December 31, 2012. See JAY RITTER, INITIAL PUBLIC OFFERINGS: UPDATED STATISTICS 12 (2013), http://bear.warrington.ufl.edu/ritter/IPOs2012Statistics.pdf. In addition, the aggregate dollar version of capital raised in all IPOs between January 1, 2001, and December 31,2012 , was $\$ 315.43$ billion, compared with $\$ 3.905$ billion raised in online IPOs. Id. at 3. Omitting the Google auction, the aggregate amount of capital raised in the same time period in auctions as $\$ 2.239$ billion. Id. at 29 . By both numbers of offerings and aggregate amount of offerings, auctions appear to represent approximately one percent of the U.S. IPO market. Id. at 29-30. This percentage may be exaggerated, however, as it compares the total number of auction IPOs with the number of operating company IPOs, which omits other types of IPOs, including REITs, SPACs, S\&Ls, foreign corporations already listed elsewhere, and unit trusts. Id. at 2.

65. Peter B. Oh, The Dutch Auction Myth, 42 WAKE ForEsT L. REV. 853, 885-87 (2007) (arguing that auction IPOs are not more efficient than bookbuilding because of a $20.3 \%$ average first day pop).

66. Ritter, supra note 65 , at 29.

67. Id. at $29-30$.

68. Id.

69. Id 
reduce the first-day share price increase to zero, then, on average, the IPO auction is well-suited to that goal. ${ }^{70}$

\section{The Death of the Online Auction IPO}

Other than the Truett-Hurst IPO in 2013, Hambrecht + Co. has not hosted an online auction IPO since 2008. In other words, no issuer that is not owned by William Hambrecht has chosen an online auction IPO in over five years, compared to over three hundred thirty bookbuilding IPOs during that same period. ${ }^{71}$ The one IPO that might have been a turning point for the auction process was Google. The Google IPO, however, was fraught with legal and technical problems, and ended up being fairly bad publicity for the auction method. ${ }^{72}$

The conventional wisdom is that IPO auctions are challenging because an issuer has to forego a Wall Street investment bank ${ }^{73}$ and the analysts and institutional investors that come with it. ${ }^{74}$ If IPO shares are "sold, not bought," then an auction IPO loses out on the selling efforts of the brand name investment bank. ${ }^{75}$ Venture-capital backed firms in particular tend to want to stick to cultivated relationships with investment banks. ${ }^{76}$ Besides path dependence, issuers may realize that the value add-

70. Ironically, financial reporters tend to characterize IPOs without a first-day price increase as disappointing, creating a Catch-22 for auction IPOs. If an online auction IPO has a first-day pop, then critics argue that the auction is no better than the bookbuilding method. If the online auction IPO does not have a first-day pop, then the IPO is viewed as unsuccessful. See Phil Wahba, Michaels Heary Debt Weighs on Market Debt, FORTUNE (June 27, 2014), http://fortune.com/2014/06/27/michaels-ipodisappointment/.

71. William Hambrecht, head of WR Hambrecht $+\mathrm{Co}$, had a stake in Truett-Hurst at the time it went public. Telis Demos, A Different Kind of Wine Auction, WALl St. J. MONEYBEAT BLOG (Apr. 17, 2013, 12:36 PM), http://blogs.wsj.com/moneybeat/2013/04/17/a-different-kind-of-wineauction/. See Hurt, Disintermediation, supra note 8, at 733-34 (describing Google's hybrid model and its unique attempt to have the Wall Street demand network along with the less costly online IPO).

72. See Hurt, Disintermediation, supra note 8, at 733-36 (describing Google's attempt to combine the demand networks of Morgan Stanley and Credit Suisse First Boston with the democratic branding of the online auction). Many of the noted missteps of Google included (1) initially requiring bidders to have a Morgan Stanley or CSFB account with a high balance; (2) having a complicated twostage bidding process; (3) pricing the issue below the auction "clearing price"; (4) declaring the auction open in August, prime vacation time for many bidders; (5) encountering legal problems from violating SEC rules by having too many existing shareholders and giving an interview to Playboy magazine that was published during the "quiet period." Id. Moreover, institutional investors were said to have boycotted the auction process, only to purchase shares in the aftermarket, causing the price to steadily increase. See also Hurt, Google, supra note 7, at 425-27.

73. See Jeff Sommer, No Bitter Aftertaste from this Stock Offering, N.Y. TIMES, Feb. 18, 2012, http:/www.nytimes.com/2012/02/19/your-money/an-ipo-process-that-is-customer-friendly.html?pagew anted=all\&_ $\mathrm{r}=0$ (quoting Professor Matthew Rhodes-Kropf of the Harvard Business School as saying "Wall Street will always hate IPO auctions ... because Wall Street is all about insider access, and these auctions take it away").

74. See Michael T. Cliff \& David J. Denis, Do Initial Public Offering Firms Purchase Analyst Coverage with Underpricing?, 59 J. OF FIN. 2871, 2898-99 (2004); Laurie Krigman et al., Why Do Firms Switch Underwriters?, 60 J. FIN. ECON. 245, 248-50 (2001).

75. Scott Reeves, Google's Flub, Flop and Bomb, ForBes (Sept. 17, 2004, 6:00AM), http:// www.forbes.com/2004/09/17/cx_sr_0917ipooutlook.html.

76. See Nocera, supra note 61 , at 12 (describing situations in which Hambrecht would make a pitch for the auction IPO to "an independent-minded chief executive who found the egalitarian nature of the auction appealing" only to have the venture capital investors choose a Wall Street financial firm to run the IPO instead). 
ed by the investment bank more than compensates for the underpricing of the bookbuilding method.

Of the issuers that have tried the online IPO method, the long term share value results are mixed. With only twenty-two or twenty-three issuers in the cohort, making generalizations about returns is difficult. However, of the six issuers that chose an auction IPO following the 2004 Google IPO, none of those issuers currently trade above or even near their IPO price, if they trade at all. ${ }^{77}$ Many others have delisted or filed for bankruptcy. Another piece of evidence that might show a backlash from established Wall Street demand networks would be analyst coverage. For a public company, lack of analyst coverage can artificially depress the price of a stock. ${ }^{78}$ In keeping with a hypothesis that auction IPO firms would have low analyst coverage, of the twelve firms that have not been acquired or declared bankruptcy, three have no analyst coverage, ${ }^{79}$ two have just one analyst each covering its stock, ${ }^{80}$ and one issuer has two analysts covering its stock. ${ }^{81}$ Three high performers have robust analyst coverage. $^{82}$

77. Four of the issuers were acquired at "fire sale" prices: CryoCor $(\$ 1.35 / \mathrm{sh})$; Avalon Pharmaceuticals (.05/sh of Clinical Data/sh); Traffic.com (\$8/sh); and ForuNet, Inc. (\$2.25). See Boston Scientific Completes Acquisition of CryoCor, REUTERS (May 28, 2008, 8:35 AM), http://www.reuters. com/article/2008/05/28/idUS132403+28-May-2008+PRN20080528; Clinical Data Completes Acquisition of Avalon Pharmaceuticals, BUSINESS WIRE (May 28, 2009, 4:06 PM), http://www.businesswire. com/news/home/20090528006129/en/Clinical-Data-Completes-Acquisition-Avalon-Pharmaceuticals\#. VAjjSGSWx74; NAVTEQ Closes Acquisition of Traffic.com, BLOOMBERG (Mar. 6, 2007), http://www. bloomberg.com/apps/news?pid=newsarchive\&sid=aX3FO4NeSiUU; Yuri Itkis Gaming Trust Of 1993 Begins Tender Offer To Acquire Remaining Public Stake In FortuNet, RTT NEWs (Jan. 15, 2015, 6:11 $\mathrm{AM}$ ), http://www.rttnews.com/1181108/yuri-itkis-gaming-trust-of-1993-begins-tender-offer-to-acquireremaining-public-stake-in-fortunet-quick-facts.aspx.

78. See Romain Boissin, Orphan Versus Non-Orphan IPOs: The Difference Analyst Coverage Makes, in HANDBOOK OF RESEARCH ON IPOS 257, 258 (Mario Levis \& Silvio Vismara eds., 2013) (finding after five years that the average negative return of an IPO issuer with analyst coverage was$8.07 \%$, compared with an average negative return of $-52.95 \%$ for an IPO issuer without analyst coverage); see generally Simona Mola et al., Is There Life After the Complete Loss of Analyst Coverage?, 88 ACCT. REV. 667 (2013) (finding that companies without analyst coverage for a year were much more likely to delist than similar firms due to the name recognition benefit of analyst coverage).

79. The three forms are: Genitope (GTOP), Dover Saddlery (DOVR), and Salon.com, now Salon Media (SLNM). Genitope Corporations Analyst Stocks Recommendations, NASDAQ, http:// www.nasdaq.com/symbol/gtop/recommendations (last visited Oct. 20,2014); Dover Saddlery, Inc. Analyst Stock Recommendations, NASDAQ, http://www.nasdaq.com/symbol/dovr/recommendations (last visited Oct. 20, 2014); Salon Media Group, Inc. Analyst Stock Recommendations, NASDAQ, http:// www.nasdaq.com/symbol/slnm/recommendations (last visited Oct. 20, 2014).

80. Morningstar (MORN) and Truett-Hurst (THST). Morninsgstar, Inc. Analyst Stock Recommendations, NASDAQ, http://www.nasdaq.com/symbol/morn/recommendations (last visited Oct. 20, 2014); Truett-Hurst, Inc. Analyst Stock Recommendations, NASDAQ, http://www.nasdaq.com/symbol/ thst/recommendations (last visited Oct. 20, 2014).

81. Overstock (OSTK). Overstock.com, Inc. Analyst Stock Recommendations, NASDAQ, http:// www.nasdaq.com/symbol/ostk/recommendations (last visited Oct. 20, 2014).

82. Google (GOOG) has nineteen firms covering its stock. Google.com Analyst Stocks Recommendations, NASDAQ, http://www.nasdaq.com/symbol/goog/recommendations (last visited Oct. 20, 2014). Rackspace Hosting (RAX) has sixteen firms covering its stock. Rackspace Hosting, Inc Analyst Stocks Recommendations, NASDAQ, http://www.nasdaq.com/symbol/rax/recommendations (last visited Oct. 20, 2014). NetSuite (N) has eight firms covering its stock. NetSuite Analyst Stocks Recommendations, NASDAQ, http://www.nasdaq.com/symbol/n/recommendations (last visited Oct. 20, 2014). A cursory, nonscientific exploration of analyst coverage for other technology firms yields the following: Facebook (FB) has seventeen firms covering its stock; Zynga (ZNGA), ten; Groupon (GRPN), thirteen; 


\section{THE WILD WEST DAYS OF CROWDFUNDING}

The vast majority of these crowdfunding projects seek altruistic or artistic funding, but many sites, such as Kickstarter, feature entrepreneurs with projects that have commercial promise ${ }^{83}$ To encourage backers of projects that either are truly charitable or may not be profitable for a long time or ever, artists or entrepreneurs may offer products or rewards, ${ }^{84}$ but anything more is legally problematic. Generally, five categories have emerged: (1) donor crowdfunding, (2) reward crowdfunding, (3) prepurchase crowdfunding, (4) non-interest-bearing loan crowdfunding, and (5) return crowdfunding. ${ }^{85}$ As the names suggest, donor crowdfunding involves backers pledging money without receiving anything in return..$^{86}$ Donors in reward crowdfunding receive public radio-type "rewards" that increase in attractiveness at higher levels of giving. ${ }^{87}$ In prepurchase crowdfunding, entrepreneurs promise delivery of a finished commercial product, financed through the project offering, either for free or at a discount; ${ }^{88}$ however, this promise of an early delivery seems to be

LinkedIn (LNKD), 11. Facebook Analyst Stocks Recommendations, NASDAQ, http://www.nasdaq.com/ symbol/fb/recommendations (last visited Oct. 20, 2014); Zynga Analyst Stocks Recommendations, NASDAQ, http:/www.nasdaq.com/symbol/znga/recommendations (last visited Oct. 20, 2014); Groupon Analyst Stocks Recommendations, NASDAQ, http:/www.nasdaq.com/symbol/grpn/recommendations (last visited Oct. 20, 2014); LinkedIn Analyst Stocks Recommendations, NASDAQ, http://www.nasdaq. $\mathrm{com} / \mathrm{symbol} / \mathrm{lnkd} / \mathrm{recommendations} \mathrm{(last} \mathrm{visited} \mathrm{Oct.} \mathrm{20,} \mathrm{2014).}$

83. For example, Kickstarter projects include consumer products, books, songs, graphic novels, and films that are meant to someday be commercial successes. Kickstarter backers have backed movie projects that did not initially attract investor funding, such as the Veronica Mars Movie and Zach Braff's movie Wish I Was Here. See Maria Elena Fernandez, Zach Braff Sold His Movie, Kickstarter Backers Await Rewards, NBC NEws (Jan. 22, 2014, 11:45 AM), http://www.nbcnews.com/popculture/movies/zach-braff-sold-his-movie-kickstarter-backers-await-rewards-n14031 (reporting that after the Sundance Film Festival, Braff sold the distribution rights to his movie to Focus Features for $\$ 2.75$ million, but many crowdfunders had yet to receive their promised rewards). Actor James Franco criticized Braff for using Kickstarter to fund a movie, the proceeds of which would go to Braff. Margaret Eby, James Franco Slams Zach Braff's Kickstarter Campaign, N.Y. DAILY NEws (July 2, 2013, 4:08 PM), http:/www.nydailynews.com/entertainment/tv-movies/james-franco-slams-zach-braffkickstarter-campaign-article-1.1388496.

84. Most sites encourage the offering of some type of "reward," "perk," or "the Goods." See How It Works, STARTSOMEGOOD, https://startsomegood.com/HowItWorks\#StepOneC (last visited Oct. 20, 2014) ("Rewards offer a way to show gratitude to your supporters and allow them to form a stronger connection with your cause. They're a tangible reminder to your supporters of the part they played in getting your project off the ground. The more directly relevant they are to the impact you'll make, the more connected supporters will feel towards your cause. The best rewards are unique, relevant and desirable.").

85. C. Steven Bradford, Crowdfunding and the Federal Securities Laws, 2012 Colum. Bus. L. REV. 1, 14-15 (2012) [hereinafter Bradford, Federal Securities].

86. Fundraising by individuals and non-profits receive no tangible rewards on sites such as Crowdrise, but the platform may run promotions and contests for donors. See Promotions, CROWDRISE.COM, http://www.crowdrise.com/give/promotions (last visited Oct. 20, 2014). (featuring contests to win Beats headphones and iPad minis).

87. Great Perk Ideas, INDIEGOGO, http://support.indiegogo.com/hclen-us/articles/201875343Great-Perk-Ideas (last visited Oct. 20, 2014) ("Perks enable you to engage fans, build trust and provide an opportunity for more people to get involved. You can offer one-of-a-kind experiences, special acknowledgments or limited supply products.").

88. The most famous prepurchase crowdfunding story is the Pebble watch, a product of Pebble Technology. Eric Migicovsky, the founder, had trouble getting funding, even though he participated in Y Combinator, a popular Silicon Valley accelerator. His Kickstarter project set a target of $\$ 100,000$ to produce a smartwatch, and within a month he raised $\$ 10$ million from 69,000 backers. See Jason Fell, 
unenforceable or at least conditional upon the project being operationally successful. ${ }^{89}$ Finally, Kiva is the most well-known example of lenders loaning small amounts of money with an expectation of having the principal loan amount returned, but not with interest. ${ }^{90}$

These first four types of crowdfunding are examples of patron funding: project supporters, whether they consider themselves donors or funders or backers, are giving the project owners either the permanent or temporary free use of their capital for very little in return. If the project owner has created its rewards or prepurchases strategically, the funds received will dwarf the cost of the token awards, however creative or interesting. ${ }^{91}$ Patrons choose projects that they believe are important, inspiring, or even urgent. Patron crowdfunding has flourished for many reasons, not the least of which is that donations, gifts, and prepurchase are unregulated beyond basic laws of fraud and deception. If patrons want to give money, then laws are unnecessary to give them much more protection than that they were not duped into giving.

Projects or enterprises ${ }^{92}$ that promise funders a return on their investment face a much different legal landscape. Crowdfunding in which the funder anticipates the possibility of a return, or investor crowdfunding, creates many more problems for both the portal and the parties.

\section{A. Investor Crowdfunding}

Both equity crowdfunding and debt crowdfunding with an expectation of interest offer a return on a backer's investment above and beyond a thank you card or DVD, but these types of platforms involve significant legal issues. The Securities Act and the Exchange Act, as well as state securities laws, regulate financial products that are deemed to be "securities." Section 2(a)(1) of the Securities Act defines this term as including various types of investments, including notes, stock, bonds, debentures, puts, calls, straddles, options and a catch-all category of "in-

Pebble's \$10 Million Crowdfunding Secret: Keep it Simple, ENTREPRENEUR (Oct. 24, 2013), http:// www.entrepreneur.com/article/229427.

89. Most prepurchase Kickstarter projects do not deliver finished goods on time, and five percent never do. See Ethan R. Mollick, The Dynamics of Crowdfunding: An Exploratory Study, 29 J. BUS. VENTURING 1, 12 (2014) [hereinafter Mollick, Dynamics] (stating that seventy-five percent of projects deliver products late, and that the more overfunded (overordered) a product is, the more likely there will be manufacturing and shipping delays).

90. See Lisa T. Alexander, Cyberfinancing for Economic Justice, 4 WM. \& MARY BUS. L.J. 309, 349-50 (2013) (recommending less regulation of peer-to-peer lending in the United States and describing the Kiva model); Sarah B. Lawsky, Money for Nothing: Charitable Deductions for Microfinance Lenders, 64 SMU L. REV. 1525 (2008) (discussing the proposal that Kiva lenders receive tax deductions in the form of a charitable donation equaling the foregone interest on their Kiva loan).

91. See Fernandez, supra note 84 (quoting a backer of Zach Braff's movie and frequent Kickstarter backer as saying, "[i]f something resonates with me in a particular way, I'll back it").

92. Professor Sean O'Connor distinguishes between project crowdfunding, in which backers provide funds for a particular project, and enterprise crowdfunding, in which backers provide funds to an enterprise for general operating expenses. See Sean M. O'Connor, Crowdfunding's Impact on StartUp IP Strategy, 21 GEO. MASON L. REV. 895, 895 (2014). Equity crowdfunding, in which backers receive shares in a legal entity, is necessarily enterprise crowdfunding. Id. 
vestment contract." 93 Types of financial products that are not specifically listed or exempted will be considered "investment contracts" and thus "securities" if they meet the test devised in SEC v. W.J. Howey Co. ${ }^{94} \mathrm{Un}$ der this test, contracts such as certain partnership interests, ${ }^{95}$ limited liability company interests, ${ }^{96}$ and condominiums ${ }^{97}$ may be securities if participants invest "money in a common enterprise and [are] led to expect profits solely from the efforts of a promoter or a third party." ${ }^{98}$ The sale of equity participation by project owners to crowdfunders will fail the Howey test.

Debt crowdfunding fares no better; courts have developed a separate test, the Reves test, ${ }^{99}$ to determine whether a note, which is listed within the Section 2(a)(1) definition of a security, might nevertheless rebut that presumption and be exempt. ${ }^{100}$ Notes that bear a "family resemblance" to any of those listed by the Reves court will be considered not to be securities. ${ }^{101}$ The listed notes are exempted based on the purpose of the borrower in entering into the obligation, the plan of distribution, the reasonable expectation of the investing public, and whether an alternative regulatory scheme exists to reduce the risk of the instrument: ${ }^{102}$

The note delivered in consumer financing, the note secured by a mortgage on a home, the short-term note secured by a lien on a small business or some of its assets, the note evidencing a "character" loan to a bank customer, short-term notes secured by an assignment of accounts receivable, or a note that simply formalizes an open-account debt incurred in the ordinary course of business (par-

93. Securities Act of 1933,15 U.S.C. $\$ 77(b)(1)$ (2012).

94. 328 U.S. 293, 298-301 (1946).

95. Generally, general partnership interests are presumed not to be investment contracts, but limited partnerships are, given that GP interests are usually active in nature, though LP interests are passive. See SEC v. Merchant Capital, LLC, 483 F.3d 747, 755 (11th Cir. 2007) (holding that partnership interests described as general partnership interests in limited liability partnerships were nevertheless securities because the "general partners" had little or no management control in fact and were too inexperienced and unknowledgeable to exercise that control).

96. Limited liability company interests may constitute investment contracts under the Howey test depending on the level of management control the membership interests retain. See Robinson v. Glynn, 349 F.3d 166, 170-72 (4th Cir. 2003) (holding that LLC interest was not an investment contract when member had negotiated for management control and held officer positions).

97. Though real estate interests are not securities, condominium units may be considered securities if elements of the Howey test are met, such as the purchase including participation in a rental pooling agreement. See Hocking v. Dubois, 885 F.2d 1449, 1458 (9th Cir. 1989) (en banc) (holding that issues of fact existed as to whether rental pool was part of purchase agreement so as to create a common enterprise). See also Guidelines as to the Applicability of the Federal Securities Laws to Offers and Sales of Condominiums or Units in a Real Estate Development, Securities Act Release No. 5347, 1973 WL 158443 (Jan. 4, 1973).

98. Howey, 328 U.S. at 298-99. The Howey test has been applied to very creative structures designed as attempts to circumvent securities laws. See SEC v. SG Lid., 265 F.3d 42, 44 (1st Cir. 2001) (holding that virtual shares that were part of an internet "fantasy" investment game were investment contracts under the Howey test).

99. Reves v. Emst \& Young, 494 U.S. 56, 67 (1990).

100. Id.

101. Id.

102. Id. at 66-67. 
ticularly if, as in the case of a customer of a broker, it is collateralized). ${ }^{103}$

The issuance of a note by a project owner to an investor crowdfunder, with an obligation to pay interest on borrowed funds, will in all likelihood fail the Reves test. ${ }^{104}$

\section{Debt Crowdfunding}

Debt crowdfunding is a way to combine the power of the Internet to join individual lenders with the growing trend of microlending. For many years, microfinance, particularly the making of microloans to small business owners in developing nations, has been believed to be a powerful force in alleviating poverty among "the poorest of the poor." 105 Correcting a market failure that results in the very poor not having access to credit, microfinance promises to "disrupt" the status quo and transform on a global scale. ${ }^{106}$ As an alternative to direct philanthropic and governmental aid to developing countries, delivering business microcredit ${ }^{107}$ and other banking services to the poor in those nations has been seen as a way to empower and equip microentrepreneurs to increase their financial stability. Supporters as diverse as $\mathrm{Bono}^{108}$ and the Bill and Melinda Gates Foundation ${ }^{109}$ have testified as to the vast, unharnessed potential of microfinance.

Kiva has been a very successful model for combining patron crowdfunding and microfinance, enabling individual would-be lenders in developed economies to invest in individual entrepreneurs in developing economies. Kiva's model of patron crowdfunding does not promise the patron lender any interest on the microloan upon repayment-only the

103. Id. at 65 (citing Chem. Bank v. Arthur Andersen \& Co., 726 F.2d 930, 939 (2d Cir. 1984)).

104. Though the Reves court specifically held that notes should not be analyzed under the Howey test because they are specifically listed in the definition of "security," a crowdlending site received a Cease and Desist Order from the SEC on the grounds that promissory notes to crowdfunders were securities under both the Howey and the Reves tests. See In re of Prosper Marketplace, Inc., Securities Act Release No. 8984, 94 SEC Docket 1913 (Nov. 24, 2008) (holding that notes issued by Prosper to crowdlenders were securities).

105. Business participants in emerging markets use various terms to describe the poor. "Bottom of the Pyramid," or BOP, is used to describe the four billion people on the earth that survive on $\$ 3000$ or less a year. See ELISABETH RHYNE, MICROFINANCE FOR BANKERS AND INVESTORS: UNDERSTANDING THE OPPORTUNITIES AND CHALLENGES OF THE MARKET AT THE BOTTOM OF THE PYRAMID 3 (2009). The "poorest segment of humanity" is often used to describe the one billion people who exist on no more than $\$ 1$ a day. $I d$. An additional billion people exist on more than $\$ 1$ a day, but less than $\$ 2$.

106. See BeAtriz ARMEndáRIZ \& Jonathan MoRduch, The ECONOMics of Microfinance 2 (2d ed. 2010) ("For many observers, microfinance is nothing short of a revolution or a paradigm shift.").

107. In this Article, the term "microcredit" is used interchangeably with "microloan" to describe a small-scale loan.

108. 10 Questions for Bono, N.Y. TIMES, Sept. 21, 2005, http://www.nytimes.com/2005/09/21/ readersopinions/bono-questions.html?pagewanted=all.

109. Press Release, Bill \& Melinda Gates Foundation, Grants Signal New Movement Toward Savings Accounts for the Poor (January 13, 2010), available at http://www.gatesfoundation.org/MediaCenter/Press-Releases/2010/01/Grants-Signal-New-Movement-Toward-Savings-Accounts-for-thePoor. 
repayment of principal. Kiva encourages patron lenders to reinvest that principal in a subsequent loan to another entrepreneur, edging the model closer to a donation model. ${ }^{110}$ Early in Kiva's history, some commenters wondered if Kiva was issuing securities, but the loans in Kiva's model were arguably not securities for at least two reasons: first, investors were not putting money at risk with an expectation of return under the Howey test; and second, a peer-to-peer ("P2P") loan does not seem like a security under the "family resemblance" test or the four principles behind the "family resemblance" list."11 The second argument came under fire when users learned that specific loans were not being made to individual borrowers but to investment funds in that borrower's community. ${ }^{112}$ However, the first argument prevailed.

The first argument, that Kiva lenders were not expecting a return, evaporates when a P2P lending model promises the lender interest on the loan. A loan from a Kiva fund to the microborrower probably is not a security under the Reves test for the same reason that bank character loans or mortgages are not. Particularly if that loan is made by a lending institution under an alternative regulatory scheme, the microborrower is hardly going to be deemed an issuer of securities. The note that crowdfunders receive from the intermediary, however, probably is a security if the crowdfunder expects a profit.

Though the term "microfinance" conjures up visions of rural microborrowers in subsistence economies, many have tried to transplant the idea in developed economies such as the United States. Prosper and Lending Club are two P2P lending sites that claim to connect returnseeking investors with worthy loan applicants. ${ }^{113}$ Prosper crowdlenders receive "Borrower Payment Dependent Notes" from Prosper, and borrowing members receive loans from WebBank, each time a crowdlender chooses to fund a particular borrower. ${ }^{114}$ Interest rates, depending on the rating of the borrower, range from "AA" to "HR."

110. See How Kiva Works, KIVA, http://www.kiva.org/about/how (last visited Oct. 20, 2014).

111. See Bradford, Federal Securities, supra note 86, at 35 (reasoning that because Kiva's investors do not expect a return, then Kiva is not offering a security under either the Howey or the Reves test).

112. See Stephanie Strom, Confusion on Where Money Lent via Kiva Goes, N.Y. Times, Nov. 9, 2009 , at B6 (reporting that money transferred to Kiva goes to funds that loan to individual borrowers, not to the borrowers the patron lender chose).

113. Peer-to-Peer Lending for Your Investment Strategy, PROSPER, http://www.prosper.com/ invest/peer-to-peer-lending/ (last visited Oct. 20, 2014) ("Help hardworking families escape the credit card trap, fund an entrepreneur's dream, or finance a dream wedding-while earning a healthy return. Through Prosper.com, borrowers get fixed-rate personal loans that are smarter alternatives to highinterest rate credit card debt that could take years to pay off. With easy monthly payments of principal and interest to investors like you, borrowers get what they want without getting deeper into debt. Take a look at our loan listings. These are real people with real stories, wants and needs."). A More Efficient Model, LENDINGCLUB, http://www.lendingclub.com/public/more-efficient-model.action (last visited Oct. 20, 2014) ("By allowing our members to directly invest in and borrow from each other, we avoid the cost and complexity of the banking system and pass the savings on to you. Both sides can win: better rates to borrowers and better returns to investors. It's that simple.").

114. Legal Compliance, PROSPER (June 30, 2011), http://prosper.com/legal/compliance/.

115. Why Invest with Prosper?, PROSPER, (last visited Oct. 20, 2014). According to the Prosper website, rates range from $5.65 \%$ to $11.08 \%$. Id. 
vestors commit to purchasing "Prime Consumer Notes" in the amount of $\$ 25$ or more, with the proceeds to be used to fund a member loan with a rating of between "A1" and "G5," with riskier member loans promising higher interest rates. ${ }^{116}$ The loans to the borrowers are also originated by WebBank, and the Prime Consumer Notes are issued by Lending Club. ${ }^{117}$ Both the Prosper notes and the Lending Club notes are not guaranteed and are contingent on the borrower repaying the underlying loan, with Prosper and Lending Club generally not bearing the risk of repayment. ${ }^{118}$ Both of these sites have had to become regulated by the SEC in order to legally continue their lending programs, ${ }^{119}$ and each registers the notes it issues with the SEC. ${ }^{120}$ The regulatory scrutiny applied to these enterprises has surely slowed the advance of microlending, particularly crowdfunded microlending, in the United States. ${ }^{121}$ The Peer-to-Peer Finance Association of the United Kingdom, on the other hand, lists nine platforms for U.K. borrowers and lenders. ${ }^{122}$

\section{Equity Crowdfunding}

The offer and sale of stock or shares in a corporation clearly involves the offer and sale of securities under the plain language of Section 2(a)(1). Likewise, the offer or sale of an investment interest in a limited partnership, limited liability company, or even unincorporated project may be a security under the Howey definition of "investment contract."123 Like debt crowdfunding, equity crowdfunding, the sale of participatory

116. Earn Solid Returns, LENDING CLUB.COM, http://www.lendingclub.com/public/steadyreturns.action (last visited Oct. 20, 2014); How Does Peer Lending Work?, LENDING ClUB.COM, http://www.lendingclub.com/public/how-peer-lending-works.action (last visited Oct. 20, 2014). According to the Lending Club website, average borrower rates as of June 30,2014 were $7.71 \%$ to $24.63 \%$. Id.

117. See Legal Compliance, PROSPER, supra note 115; Risks of Investing, LENDING CluB, http:// www.lendingclub.com/public/risk-of-investing.action (last visited Oct. 20, 2014).

118. Id.

119. See Prosper Marketplace, Inc., Securities Act Release No. 8984, 94 SEC Docket 1913 (Nov. 24,2008 ) (holding that notes issued by Prosper to crowdlenders were securities).

120. See, e.g., Prosper Funding LLC \& Prosper Marketplace Inc., Registration Statement (Form S-1) (Dec. 21, 2012), available at https:/www.sec.gov/Archives/edgar/data/1416265/00011 4036112052353/forms1a.htm; Lending Club Corporation, Registration Statement (Form S-1) (Aug. 27, 2014), available at http://www.sec.gov/Archives/edgar/data/1409970/000119312514323136/d76681 1ds1.htm.

121. See generally Andrew Versteen, The Misregulation of Person-to-Person Lending, 45 U.C. DAvis L. ReV. 445 (2011) (describing the regulation of both Prosper and Lending Tree). Recently, Ohio regulators issued a Cease and Desist Order against SoMoLend Holdings, LLC alleging, among other things, selling unregistered notes without an exemption, not being registered as a broker-dealer, and securities fraud. See In the Matter of SoMoLend Holdings, LLC, No. 13-022, 2013 WL 3243088 (Ohio Dep't Commerce June 14, 2013); Josh Pichler, State Reaches Settlement with SoMoLend, but Future Uncertain, CINCINNATI ENQUIRER, Feb. 12, 2014, available at 2014 WLNR 4010146 (explaining that settlement allows SoMoLend to continue, but founder not subject of settlement).

122. See Members, PEER2PEER FINANCE AsSOCIATION, http://www.p2pfinanceassociation.org.uk/ (last visited Oct. 20, 2014).

123. See SEC v. Shields, 744 F.3d 633, 642-43, 645-45, 648 (10th Cir. 2014) (holding that "joint venture agreements" were investment contracts under Howey test). 
interests to the general public over the Internet, will violate the Securities Act by selling unregistered securities without an exemption. ${ }^{124}$

Though an IPO is the regulated venue for raising equity capital through offerings to the public, SEC regulations provide various avenues for privately placing securities with investors in nonpublic offerings. ${ }^{125}$ Section 4(2) of the Securities Act prohibits only "public" offerings, creating a window for private offerings of securities, while Section 3(b) lists three safe harbors found in Regulation D: Rule 504, Rule 505, and Rule $506 .{ }^{126}$ Rules 504 and 505 were promulgated under Section 3(b) and allow private offerings of up to $\$ 1$ million and $\$ 5$ million, respectively; Rule 506 , promulgated under Section 4(2), allows offerings of unlimited amounts of securities to accredited investors and a small number of unaccredited investors. ${ }^{127}$

Very few crowdfunding projects to date have exceeded even the $\$ 1$ million limit of Rule 504, suggesting that any of the Regulation D exemptions may be available for crowdfunders. However, each rule has limitations that preclude use by crowdfunded projects. ${ }^{128}$ In particular, until very recently, one of the hallmarks and requirements of these safe harbors is that the offering may not be a "general solicitation" to the public. ${ }^{129}$ Crowdfunding via an Internet website walks a strange path between regulated public offerings and exempt private placements; crowdfunding generally seeks to attract small amounts of capital, as in a private placement, but in a very public offering from large numbers of investors. In addition, Rules 505 and 506 limit the number of "unaccredited" investors

124. In November 2009, Michael Migliozzi II and Brian William Flatow solicited funds via website ("BuyaBeerCompany.com") to purchase Pabst Brewing Company. See In the Matter of Migliozzi II, Securities Act Release No. 9216 (June 8, 2011) (accepting settlement of desisting from fundraising efforts, which violated Section 5 of the Securities Act). Funders were promised "crowdsourced certificates of ownership" and beer should the offer be successful and monies collected. Id. The website, advertised via Facebook and Twitter, raised $\$ 200$ million pledges from five million investors. Id. However, the SEC issued a Cease and Desist Order to halt the project. Id. Pabst was eventually sold for $\$ 250$ million to investor C. Dean Metropoulos's investment vehicle, Metropoulos \& Co. See Tom Daykin, New Pabst Owner Promises to Build Sales, MilwaukeE J. Sentinel, June 28, 2010, http://www. jsonline.com/business/97357129.html.

Currently, Metropoulos is seeking a buyer for Pabst. See Denise Lockwood, Pabst Brewing Company Owner Wants to Sell, MILWAUKEE Bus. J. (Mar. 4, 2014), http://www.bizjournals.com/milwaukee/ news/2014/03/03/pabst-brewing-company-owner-wants-to.html (reporting that Markopoulos was considering either a private sale or an IPO).

125. Regulation A also provides for "mini-registration" for small offerings, but it is rarely used compared with the other exemptions, particularly Rule 506. See Rutherford B. Campbell, Jr., Regulation A: Small Business' Search for 'A Moderate Capital,' 31 DEL. J. CORP. L. 77, 83 (2006) (finding that Regulation A registration was used an average of eight times a year).

126. Securities Act of 1933, 15 U.S.C. $\$ 77 \mathrm{~d}(2012) ;$ id. $\$ 77 \mathrm{c}$ (b) (2012).

127. Id. $\$ 77 \mathrm{c}$ (b); 17 C.F.R. $\$ 230.504$ (2014); 17 C.F.R. $\$ 230.505 ; 17$ C.F.R. $\S 230.506$.

128. For example, shares issued under Rule 504 are restricted and cannot be resold without registration 17 C.F.R. $\$ 230.504$ (2014). Rule 505 and 506 require suitable disclosures to be given to unaccredited investors, which are limited in number to thirty-five. Id. at 17 C.F.R. $\S 230.505 ; \S 230.506$ (2014).

129. See infra Section V.D.2 (discussing the JOBS Act's elimination of the prohibition against general solicitation for Rule 506 offerings). 
that may participate in the offering. ${ }^{130}$ Because general solicitation of investments necessarily involves hundreds if not thousands of investors, many of whom would not qualify as accredited investors, a crowdfunding offering by its very nature does not qualify as an exempt private placement under any exemption. ${ }^{131}$

Interestingly, one of the more difficult exemptions for startup companies to satisfy in a traditional private placement may prove to be the only exemption suitable for pre-JOBS Act crowdfunding. Section $3(\mathrm{a})(11)^{132}$ exempts intrastate offerings of any size, as long as all offerees and purchasers are residents of the same state, and the issuer is both incorporated and headquartered in that state. Several states have passed or are considering intrastate crowdfunding regulations ahead of final regulations for federal crowdfunding, making crowdfunding efforts that meet the requirements of intrastate offerings exempt from both state and federal regulation..$^{133}$ As studies have shown that much of crowdfunding is used for local projects, smaller businesses may do well to launch strictly local offerings to those in their community, who may get a larger sense of civic pride in participating. Section 3(a)(11), however, restricts "offerees" to residents, so portals have to exact detailed information from browsing would-be crowdfunders before letting them view detailed projects. ${ }^{134}$

130. See 17 C.F.R. $\&$ 230.501(a)(5)-(6) (2014) (defining "accredited investor" as a person: “(1) whose individual net worth, or joint net worth with that person's spouse, exceeds $\$ 1$ million, excluding the value of the person's primary residence" (the "net worth test"); or "(2) who had an individual income in excess of $\$ 200,000$ in each of the two most recent years, or joint income with that person's spouse in excess of $\$ 300,000$ in each of those years, and has a reasonable expectation of reaching the same income level in the current year" (the "income test")." Many critics urged Congress or the SEC to increase these tests as part of the Dodd-Frank Act due to the tests not having been amended in decades and not being indexed for inflation. The only change that was made, however, was to exclude the value of a person's primary residence from the calculation of net worth. See The Dodd-Frank Wall Street Reform and Consumer Protection Act, Pub. L. No. 111-203, 124 Stat. 1376, 1577 (2012).

131. See generally Joan MacLeod Heminway \& Sheldon Ryan Hoffman, Proceed at Your Peril: Crowdfunding and the Securities Act of 1933, 78 TENN. L. REV. 879 (2011) [hereinafter Heminway \& Hoffman, Peril] (analyzing relevant federal securities law and determining that equity crowdfunding participations were investment contracts and therefore securities).

132. Id. $\$ 77 \mathrm{c}$ ("Any security which is a part of an issue offered and sold only to persons resident within a single State or Territory, where the issuer of such security is a person resident and doing business within or, if a corporation, incorporated by and doing business within, such State or Territory.").

133. See, e.g., ALA. CODE \& 8-6-11 (2014), available at http://alisondb.legislature.state.al.us/acas/ ACASLoginfire.asp; Invest Georgia Exemption, GA. CODE ANN. $§ 590-4-2 .-08$ (2014); S. 375, 118th Indiana Gen. Assembly (2014) (effective July 1, 2014), available at http://iga.in.gov/legislative/ 2014/bills/senate/375/\#; Invest Kansas Exemption, KAN. STAT. ANN. § 81-1-1 (2014), available at http:// www.sos.ks.gov/pubs/kar/2009/4\%20081_81-Office\%20of\%20the \%20Securities\%20Commissioner\%2 02009\%20KAR\%20Vol\%204.pdf; Michigan Invests Locally Exemption Act, MiCH. COMP. LAWs § 451.2202a (2014), available at http://www.legislature.mi.gov/(S(tqbdx1552qcvmd55kbpzbl55))/ documents/mcl/pdf/mcl-451-2202a.pdf; Washington JOBS Act of 2014, WASH. REV. CODE $\$ 42.56 .270$ (2014), available at http://apps.leg.wa.gov/documents/billdocs/2013-14/Pdf/Bills/Session\%20Laws/ House/2023-S.SL.pdf; WIS. STAT. $\S 551.202(13)$ (ar) (West 2014), available at https://docs.legis. wisconsin.gov/statutes/statutes/551.pdf\#page $=6$. Legislation in other states, such as North Carolina, has been proposed. See, e.g., North Carolina Jumpstart Our Businesses Act, N.C. GEN. STAT. § 78A-17.1 (2014), available at http://www.ncleg.net/Sessions/2013/Bills/House/PDF/H680v4.pdf.

134. See LOCALSTAKE LLC, http://localstake.com (last visited Oct. 20, 2014). When I visited this site, I was asked to first sign up to enter the site, then I was asked to set up a funding account, which required my address, social security number, and driver license number, among other things. See also GROUNDFLOOR, http://groundfloor.us (last visited Oct. 20, 2014). When I registered for this site, it 
Professor Joan Heminway has aptly analogized equity crowdfunding to file sharing in the music industry. ${ }^{135}$ Like file sharing, equity crowdfunding is almost impossible to do legally, but too easy not to do. ${ }^{136}$

As crowdfunding publicity grew, however, so did the watchful eyes of regulators, and websites dedicated to matching for-profit entrepreneurs with equity investors went dark. ${ }^{137}$ One particularly promising site, ProFounder, argued that its site fell under the nonpublic offering exemption of Section 4(2) because only those investors invited by project founders could access the site. ${ }^{138}$ Unfortunately, California regulators avoided this argument by issuing a Cease and Desist Order based on the fact that the portal was not registered as a broker-dealer with the State of California. ${ }^{139}$

Debt crowdfunding sites were able to withstand regulation by having the site itself register with the SEC and issue notes to crowdlenders, with repayment conditional on the borrowers repaying particular loans. The preapproved borrowers have a contractual obligation to pay a fixed rate of interest, limiting the amount of risk the site bears. To create legal equity crowdfunding, only three avenues were available prior to the JOBS Act. First, each crowdfunding project could register the offered shares, incurring a cost that could far exceed the benefits of the offering. Second, equity crowdfunding sites could register shares with the SEC

sent me an email with the following language: "As soon as we're set up in your state, you'll be among the very first to know." Id. However, I was allowed to view projects and "follow" those I was interested in. Id. Text on the page listing potential projects warned me: "Information on this page is not an offer or a solicitation to sell or purchase securities. Clicking 'Follow' expresses a desire to learn more about a particular real estate project, developed by a third party independent to us. Statements on this page are for informational purposes only." Id.

135. See Joan Heminway, The New Intermediary on the Block: Funding Portals under the CROWDFUND Act, 13 U.C. DAvis Bus. L. J. 177, 189 (2013) [hereinafter Heminway, Funding Portals.].

136. Though Kickstarter's rules require projects to offer "rewards," it specifically prohibits offering securities. However, this rule was apparently not monitored. See Christine Hurt, Peer-to-Peer Microfinancing for the Arts? Looking at Kickstarter, CONGLOMERATE (July 9, 2010), http://www.the conglomerate.org/2010/07/peertopeer-microfinancing-for-the-arts-looking-at-kickstarter.html (reviewing projects on the site and finding one offering LLC shares). Many sites have at times given a platform to equity crowdfunders. See Heminway \& Hoffman, Peril, supra note 132, at 963-65 tbl.1 (listing five U.S. sites, including Kickstarter and IndieGoGo, that hosted projects offering equity participation or revenue sharing in 2011).

137. See Bradford, Federal Securities, supra note 86, at 24-25 (describing the bright future and untimely demise of ProFounder, which heralded the end to equity crowdfunding sites in the United States). ProFounder was founded by Jessica Jackley, cofounder of Kiva under the premise of crowdfunding micro-equity to entrepreneurs in the U.S. Leena Rao, Fundraising Platform for Startups Profounder Shuts its Doors, TECHCRUNCH (Feb. 17, 2012), http://techcrunch.com/2012/17/startup. fundraising-platform-profounder-shuts-its-doors/.

138. See Heminway \& Hoffman, Peril, supra note 132, at 919 n.205 (explaining that ProFounder acted not as a capital-raising mechanism but more as a communication tool for startups seeking funding from friends and family).

139. See Cal. DeP't of Corp., Consent Order to Desist and Refrain 3 (Aug. 3, 2011), available at http://www.dbo.ca.gov/ENF/pdf/2011/ProFounder_CO.pdf. Similar sites that limit capital raising from accredited investors have tried to avoid this fate by registering with the SEC, FINRA, and all applicable state regulators at substantial cost. See Angus Loten, Crowd-Funding Brings Unease, WALL ST. J., Nov. 17, 2011, http://online.wsj.com/news/articles/SB10001424052970203611404577042333 598282986 (describing the experiences of Bill Clark at MicroVenture Marketplace, Inc. and Onnie Carr at WealthForge LLC). 
and offer those shares to crowdfunders. Then, the site could be the sole accredited investor in each funded project, falling squarely within any private placement safe harbor. Each site, though, would also need to register with the SEC as an investment company regulated under the Investment Company Act, adding an additional layer of expense. Unlike debt crowdfunding sites, the equity crowdfunding sites would take on a significant amount of investment risk as well. Third, a crowdfunding site could purport to merely match accredited investors with worthy projects, walking the line between "online" and "nonpublic."140 Equity crowdfunding websites in other countries, however, have flourished.

With the passage of the JOBS Act in April 2012, the illegality of existing and past efforts to create equity crowdfunding portals in the United States became clear. ${ }^{142}$ Title III of the JOBS Act, however, created an exemption for equity (and debt) crowdfunding, though the provisions of new Section 4(6) of the Securities Act could more accurately be described as regulation than exemption.

\section{LEgAL EQUITY CROWDFUNDING UNDER THE JOBS ACT}

As the crowd awaited the new exemption, commentators disagreed on whether an exemption was long overdue or ill-conceived populism. Prior to the passage of the CROWDFUND Act, scholars worried that exempting capital raising by and among strangers over the Internet would open the floodgates to fraud. ${ }^{143}$ If the securities laws were meant to protect investors, then surely they were meant to protect the amateur in-

140. See MicroVentures, INC., www.microventures.com (last visited Oct. 20, 2014); CirCLEUP, www.circleup.com (last visited Oct. 20,2014). These accredited investor-only sites are registered as broker-dealers with FINRA. Id. Another variation is an accredited investor-only debt crowdfunding model. See FUNDING CIRCLE, www.fundingcircle.com (last visited Aug. 23, 2014).

141. According to the Crowdfunding Industry Report, in 2011, startups raised $\$ 88$ million worldwide through equity funding platforms. Gerrit K.C. Ahlers et al., Signaling in Equity Crowdfunding 10 (Social Science Research Network, Working Paper No. 2161587, 2012), available at http://ssm. com/abstract $=2161587$. Sixty-seven percent of that capital was raised on two platforms: Ireland's SeedUps and the Australian Small Scale Offerings Board (ASSOB). Id. As of April 2012, when President Barack Obama signed the JOBS Act, thirty-nine platforms operated to attract equity crowdfunding, and 452 platforms to attract any kind of crowdfunding. Id. at 9 . See also Crowdfunding: Connecting Investors and Job Creators Hearing Before the Subcomm. on TARP, Fin Servs. \& Bailout of Pub. and Private Programs of the H. Comm. on Oversight \& Gov't Reform, 112th Cong. 4 (Sept. 15, 2011) (statement of Jeff Lynn, CEO, Seedrs Limited) [hereinafter Lynn Testimony] (describing the decision to launch Seedrs in the U.K. rather than in the U.S. because of the availability of a workable securities exemption for crowdfunding).

142. See Anita Hamilton, Crowdfunding Soared to $\$ 2.7$ Billion in 2012, but Equity Crowdfunding Is Still on Ice, TIME (Apr. 8, 2013), http://business.time.com/2013/04/08/crowdfunding-soared-to-2-7billion-in-2012-but-equity-funding-is-still-on-ice/ (estimating that only four percent of crowdfunding in 2012 was equity crowdfunding because of illegality concerns).

143. See Spurring Job Growth Through Capital Formation While Protecting Investors: Hearing Before the S. Comm. on Banking, Housing \& Urban Affairs, 112th Cong. 13 (Dec. 1, 2011) (statement of John C. Coffee, Jr., Adolph A. Berle Prof. of Law, Columbia University Law School) [hereinafter Coffee Testimony] (testifying that without proper regulation, crowdfunding sites would become the new "boiler rooms"); see also Thomas Lee Hazen, Crowdfunding or Fraudfunding? Social Networks and the Securities Laws - Why the Specially Tailored Exemption Must Be Conditioned on Meaningful Disclosure, 90 N.C. L. REv. 1735, 1735 (2012). 
vestor clicking on projects created by unknown strangers. ${ }^{144}$ Retail investors, particularly unaccredited investors, are generally not invited to participate in private placements, ${ }^{145}$ and, in fact, Rules 505 and 506 create huge incentives for issuers to sell only to accredited investors. ${ }^{146}$ Any type of investor may purchase registered securities, even IPO securities, but investors are thought to be protected by required disclosures of information and gatekeepers such as underwriters, law firms, and public accounting firms. ${ }^{147}$ Securities regulation balances a tension between easy capital formation and investor protection, but a liberal crowdfunding exemption might tilt the investing landscape too much in the direction of entrepreneurs, honest, dishonest, or even fake, looking to raise capital. ${ }^{148}$ The resulting CROWDFUND Act, however, seemed to be a compromise that made no one happy.

\section{A. The CROWDFUND Act}

The CROWDFUND Act amends the Securities Act to add Section $4(6)$ and Section 4A. Section 4(6) provides that transactions involving the offer or sale of securities by an issuer will be exempt if they are sold through a broker ${ }^{149}$ or funding portal described in Section $4 A(a)$; if the issuer complies with the requirements of Section $4 \mathrm{~A}(\mathrm{~b})$; and if the aggregate offering amounts and individual investment amounts are limited. Specifically:

- The aggregate amount sold to all investors by the issuer, including any amount sold in reliance on the exemption provided under this paragraph during the twelve-month period

144. Spurring Job Growth Through Capital Formation While Protecting Investors: Hearing Before the S. Comm. on Banking, Housing \& Urban Affairs, 112th Cong. 54 (Dec. 1, 2011) (statement of Meredith Cross, Director, Div. of Corp. Fin., SEC) ("Due to the nature of crowdfunding ventures, crowdfunding investors may have limited investment experience, limited information upon which to make investment decisions, and almost no ability to negotiate for protections."); C. Steven Bradford, The New Federal Crowdfunding Exemption: Promise Unfulfilled, 40 SEC. REG. L.J. 195, 196 (2012) (describing crowdfunding as a "potentially dangerous combination of investment risk and relatively unsophisticated investors").

145. See William K. Sjostrom, Rebalancing Private Placement Regulation, 36 SEATtLe U. L. REV. 1143,1147 (2013) (describing the practical logistics of the private placement process).

146. Both Rule 505 and 506 limit the number of unaccredited investors who may participate in any offering to thirty-five, and issuers must provide those investors, but not unaccredited investors, with adequate disclosure documents. 17 C.F.R. $\$ \S 230.505$ (b)(2)(ii), 203.506(b)(2)(i) (2014).

147. See generally Christine Hurt, Counselor, Gatekeeper, Shareholder, Thief: Why Attorneys Who Invest in Their Clients in a Post-Enron World Are "Selling Out," Not "Buying In," 64 OHIO ST. L.J. 897 (2003) (discussing the roles of investment banks, accounting firms and law firms as gatekeepers to the capital markets in IPOs).

148. See Thomas A. Martin, The JOBS Act of 2012: Balancing Fundamental Securities Law Principles with the Demands of the Crowd (Social Science Research Network, Working Paper No. 2040953, 2012), available at $\mathrm{http}: / / \mathrm{ssrn}$.com/abstract $=2040953$.

149. Capital Raising Online While Deterring Fraud and Unethical Disclosure (CROWDFUND) Act, Pub. L. No. 112-106, 126 Stat. 306, $\$$ 301-305 (2012) (codified as amended in scattered sections of 12 U.S.C. and 15 U.S.C.). Most of the commentary and debate focuses on portal-enabled crowdfunding. For a discussion of whether the broker model will ever materialize, see Robert $\mathrm{B}$. Thompson \& Donald C. Langevoort, Redrawing the Public-Private Boundaries in Entrepreneurial Capital Raising, 98 CORNELL L. REV. 1573, 1607 (2013). 
preceding the date of such transaction, is not more than $\$ 1,000,000 ; 150$

- The aggregate amount sold to any investor ${ }^{151}$ by an issuer, including any amount sold in reliance on the exemption provided under this paragraph during the twelve-month period preceding the date of such transaction, does not exceed-

- The greater of $\$ 2000$ or five percent of the annual income or net worth of such investor, as applicable, if either the annual income or the net worth of the investor is less than $\$ 100,000$; and

- Ten percent of the annual income or net worth ${ }^{152}$ of such investor, as applicable, not to exceed a maximum aggregate amount sold of $\$ 100,000$, if either the annual income or net worth of the investor is equal to or more than $\$ 100,000 .^{153}$

As stated in Section 4(6), the offering must take place through an intermediary that complies with Section $4 A(a)$, which requires registration with the Financial Industry Regulatory Authority ("FINRA"). In addition, the intermediary must ensure that each investor has passed a nonspecific financial literacy test, must "take measures to reduce the risk of fraud" and "ensure that all offering proceeds are only provided to the issuer when the aggregate capital raised from all investors is equal to or greater than a target offering amount," in addition to other requirements. ${ }^{154}$ Section $4 A$ (c) also provides for liability for material misstatements and omissions for intermediaries as a "person who offers or sells the security." 155

150. Earlier versions of this legislation had higher maximum amounts. Compare Entrepreneurial Access to Capital Act, H.R. 2930, 112th Cong. $\$ 2$ (a) (2011) (as introduced, setting a $\$ 5$ million maximum amount) with Entrepreneur Access to Capital Act, H. R. 2930, 112th Cong. \& 2(a) (2011) (setting a $\$ 1$ million maximum amount and a $\$ 2$ million maximum amount if the issuer provides audited financials as passed in the House Nov. 3, 2011).

151. This limitation applies whether the investor is a retail investor, accredited investor, or institutional investor. See Proposed Regulation Crowdfunding, supra note 14, at 66,434. Issuers are free to launch a separate offering for accredited investors under a Regulation D private placement exemption at the same time, however. See 17 C.F.R. $\$ 230.504$ (2014).

152. Many comments were submitted to the SEC about this statutory ambiguity. See Proposed Regulation Crowdfunding, supra note 14, at $66,433-34$. Though the preceding provision had a "greater of" provision that applied to annual income or net worth, that language does not appear in subsection (b). In the regulations, the SEC proposes using a "greater of" calculation. Id.

153. Id. at 66,430 .

154. See Securities Act of 1933,15 U.S.C. $\$ 77 d-1(a)(8)-(12)(2012)$ (requiring intermediaries to make efforts to ensure investors do not exceed aggregate crowdfunding limits, to protect privacy of investors, not to compensate promoters or finders, and to prohibit portal or broker insiders from having financial interest in any issuer-client).

155. See id. \& 77d-1(c); see also Michael B. Dorff, The Siren Call of Equity Crowdfunding, (Social Science Research Network, Working Paper No. 2325634, 2013), available at http:/www.ssrn. com/abstract $=2325634$. The proposed SEC regulations make clear this liability could be under Section 12(a)(2) and Section 17 of the Securities Act for exempted transactions. In the summary, the SEC appears to be giving intermediaries a due diligence defense, but that assumes that the intermediaries will undertake underwriter-like due diligence: 
Though the requirement of having a registered portal that may be subject to liability seems burdensome, the disclosure requirements on crowdfunding issuers may be even more onerous. ${ }^{156}$ Section $4 \mathrm{~A}(\mathrm{~b})$ sets out details for the substances of disclosures that the issuers must make to prospective investors. ${ }^{157}$ In addition to a description of financial condition and the securities for sale, for target offering amounts of up to $\$ 100,000$, the issuer must provide one year of income tax returns and certified financial statements. ${ }^{158}$ For target offering amounts of up to $\$ 500,000$, the issuer must provide financial statements reviewed by an independent public accountant. ${ }^{159}$ Finally, for target offering amounts of more than $\$ 500,000$, the issuer must provide audited financial statements. ${ }^{160}$ The statute also provides for annual disclosures "as the Commission shall, by rule, determine appropriate." 161 Additionally, crowdfunding issuers must "not advertise the terms of the offering, except for notices which direct investors to the funding portal or broker."162 Finally, though not part of the CROWDFUND Act, the JOBS Act amended Section 12(g)(1) of the Securities Act to allow issuers to remain "nonreporting" as long as their shares are held by less than 2000 shareholders, up from $500 .{ }^{163}$ More importantly, crowdfunding investors are not included in that number. ${ }^{164}$

On the basis of this definition, it appears likely that intermediaries, including funding portals, would be considered issuers for purposes of this liability provision. We believe that steps intermediaries could take in exercising reasonable care in light of this liability provision would include establishing policies and procedures that are reasonably designed to achieve compliance with the requirements of Regulation Crowdfunding, and that include the intermediary conducting a review of the issuer's offering documents before posting them to the platform to evaluate whether they contain materially false or misleading information.

See Proposed Regulation Crowdfunding, supra note 14 , at $66,499$.

156. Some commentators urged Congress to provide investor protection through issuer disclosure; others suggested that intermediaries might be able to bear the burden of increased regulation. Unfortunately, Congress seemed to agree with both ideas. See Hazen, supra note 143, at 1750-55 (detailing earlier versions of the crowdfunding provisions and analyzing how arguments for meaningful

disclosure were paramount in the resulting form); see also Hearing on the JOBS Act-Importance of Effective Implementation, Before the Subcomm. on TARP, Fin. Servs. and Bailouts of Pub. and Private Programs of the H. Comm. on Oversight and Gov't Reform, 112th Cong. 2 (2012) (statement of C. Steven Bradford, Earl Dunlap Distinguished Professor of Law, University of Nebraska College of Law) ("To the extent that additional regulation is required, it should be centered on crowdfunding intermediaries - brokers and funding portals - rather than on the entrepreneurs raising funds.").

157. See 15 U.S.C. $\$ 77 \mathrm{~d}-1$ (b) (2012).

158. See id. $\$ 77 \mathrm{~d}-1$ (b)(D)(i).

159. See id. $\$ 77 \mathrm{~d}-1$ (b)(D)(ii).

160. See id. $\$ 77 \mathrm{~d}-1$ (b)(D)(iii).

161. See id. $\$ 77 \mathrm{~d}-1(\mathrm{~b})(4)$.

162. See id. $\S 77$ a. Presently, many project founders with Kickstarter campaigns advertise on local radio, newspapers, social media and more. These advertisements now will have to meet the requirements of Section 4A. Id.

163. See Securities Exchange of 1934, 15 U.S.C. $\& 78 \mathrm{c}$ (2012); Sjostrom, supra note 145, at 1153. Only five hundred of those shareholders may be unaccredited, though employees who hold stock received as compensation are not counted. See also Usha Rodrigues, Lies, Damned Lies and Securities Regulation, 2015 U. ILL L. REV. (forthcoming 2015) (providing data that does not seem to support the argument that companies were being pushed to IPO because they were bumping against the five hundred shareholder limit).

164. See Rodrigues, supra note 164. 
Many commentators who were hoping for an exemption that would provide a cheap and easy path to crowdfunding ${ }^{165}$ bemoaned the cost of disclosure, particularly ongoing disclosure, as well as other costly requirements. Mapping on audited financial statement requirements to the quirky and creative projects touted on websites by brand-new entrepreneurs without a corporate form did not seem to be a good fit. Section 4(6) was a bucket of cold water on fantasies of a brave new world of crowdfunding. As one industry participant has noted, the CROWDFUND Act creates a world for "Merrill Minus" offerings, not "Kickstarter Plus" offerings. ${ }^{166}$ Though the requirements were clearly less onerous and cheaper than a full-blown IPO, they were much more complex and costly than imagined. The statute did leave some of the details to the SEC to flesh out in regulations; however, the SEC could only tighten the detailed statute with more requirements, not fewer.

\section{B. Regulation Crowdfunding}

The SEC voted to release proposed ${ }^{167}$ regulations interpreting Sections 4(6) and 4A on October 23, 2013, almost two years overdue. Because Congress made the CROWDFUND Act so detailed, the SEC had very little leeway to subtract, and not much to add, to flesh out the new provisions in the Securities Act. ${ }^{168}$ As expected, the regulations did little to alleviate the restrictions of the CROWDFUND Act, ${ }^{169}$ though the

165. See Thompson \& Langevoort, supra note 150, at 1604 (stating that proponents of crowdfunding "had wanted a nearly regulation-free zone wherein startups and other early stage issuers could at little cost use the Internet, either directly or through funding portals, to display their business plan and seek out small investors who share their entrepreneurial dream, however risky it might be").

166. See Thaya Brook Knight et al., A Very Quiet Revolution: A Primer on Securities Crowdfunding and Title III of the JOBS Act, 2 MiCH. J. PVT. EQ. \& VenTURE CAP. L. 135, 137 (2013) ("To date, one of the hallmarks of crowdfunding has been its passion... [u]nfortunately, selling securities requires more than enthusiasm.").

167. Comments were open on the proposed rules for ninety days ending February 3, 2014. Deborah L. Jacobs, SEC Proposes Crowdfunding Rules, FORBES (Oct. 23, 2013, 2:41PM), http:// www.forbes.com/sites/deborahljacobs/2013/10/23/sec-proposes-crowdfunding-rules/.

168. Compare the detailed provisions of the JOBS Act to the Dodd-Frank Act, wherein Congress required the SEC to promulgate rules on ninety topics, some with little guidance. For example, Section 971 of the Dodd-Frank Act amended Section 14(a) of the Exchange Act to allow the SEC to issue rules requiring shareholder proxy access:

The rules and regulations prescribed by the Commission under paragraph (1) may include -

(A) a requirement that a solicitation of proxy, consent, or authorization by (or on behalf of) an issuer include a nominee submitted by a shareholder to serve on the board of directors of the issuer; and

(B) a requirement that an issuer follow a certain procedure in relation to a solicitation described in subparagraph $(\mathrm{A})$.

See Securities Exchange Act of 1934, 15 U.S.C. $\$ 78$ c (2012); Dodd-Frank Wall Street Reform and Consumer Protection Act, 12 U.S.C. § 5301 (2012). The proxy rules that the SEC eventually promulgated were struck down, however, by a federal district court as violating the Administrative Procedures Act. See Business Roundtable v. SEC, 647 F.3d 1144 (D.C. Cir. 2011); see also Jill E. Fisch, The Destructive Ambiguity of Proxy Access, 61 EMORY L.J. 435 (2011). Perhaps after that political debacle, Congress felt that more detail and less discretion was a better tactic.

169. But see Crowdfunding Proposal, Hearing Before the Subcomm. on Investigations, Oversight, and Regulations of the H. Comm. on Small Bus., 113th Cong. (Jan. 16, 2014) (statement of Mercer Bullard, Pres., Fund Democracy) [hereinafter Bullard Testimony] (criticizing the SEC for its interpre- 
SEC was pressured to do so by many commentators. ${ }^{170}$ The end result is that the regulations do very little to alter the arguably unworkable regime outlined by Congress. ${ }^{171}$

The criticized restrictions were left in place, including the aggregate cap of $\$ 1$ million, the disclosure requirements, ${ }^{172}$ and the portal registration requirements. The SEC did ask for comments on whether the $\$ 500,000$ trigger for audited financial statements should be increased ${ }^{173}$ and whether the $\$ 1$ million cap should be net of fees. ${ }^{174}$

The regulations did, however, attempt to alleviate some of the restrictiveness of Section 4(6) by proposing that offerings under 4(6) would not be aggregated or integrated with other exempt offerings, ${ }^{175}$ meaning that an issuer could offer crowdfunded securities within twelve months of offering securities in a separate private placement. ${ }^{176}$ For example, an issuer could raise up to $\$ 5$ million in a Rule 505 offering and up to $\$ 1$ million in a 4(6) offering by crowdfunding within the same year or even simultaneously. Of course, if the rationale behind crowdfunding is that small businesses avoid even Regulation D private placements because of

tations of the statutory language regarding integration and the currentness of financial disclosures required).

170. See, e.g., Oversight of the JOBS Act: Importance of Effective Implementation Before the Subcomm. on TARP, Fin. Servs. and Bailouts of Pub. and Private Programs of the H. Oversight \& Gov't Reform Comm., 112th Cong. (2012) (statement of Alon Hillel-Tuch, CFO, RocketHub) [hereinafter RocketHub Testimony] (urging the SEC to raise the $\$ 500,000$ threshold for providing audited financial statements and to raise the $\$ 1$ million crowdfunding cap to $\$ 5$ million).

171. See Steven M. Davidoff, Trepidation and Restrictions Leave Crowdfunding Rules Weak, N.Y. TIMES DEALBOOK (Oct. 29, 2013, 5:10PM), http://dealbook.nytimes.com/2013/10/29/trepidation-andrestrictions-leave-crowdfunding-rules-weak/ [hereinafter Davidoff, Trepidation] (reporting that the SEC "largely parroted" what Congress had set out in the CROWDFUND Act).

172. The proposed regulations do, however, allow issuers to use "financial statements for the fiscal year prior to the issuer's most recently completed fiscal year." See Proposed Regulation Crowdfunding, supra note 14, at 66,554 (Instruction 8). This has led Prof. Bullard to warn of harmful effects from the use of "stale" disclosures. See Bullard Testimony, supra note 170. Most commentators, however, worry that crowdfunding startups will not have "stale" or "fresh" financial statements, but will have to incur substantial cost to prepare them. See SEC's Crowdfunding Proposal: Will It Work for Small Businesses?, Hearing Before the Subcomm. on Investigations, Oversight, and Regulations of the H. Comm. on Small Bus., 113th Cong. (Jan. 16, 2014) (statement of Daniel S. Gorfine, Director, Milken Institute) (suggesting that targeting fraudsters was a better avenue for combatting fraud than requiring startups to prepare traditional disclosures).

173. See Securities Act of 1933,15 U.S.C. $\$ 77$ a (2012) (requiring audited financial statements for target offering amounts of more than $\$ 500,000$ "or such other amount as the Commission may establish, by rule"). But see Bullard Testimony, supra note 170 (criticizing the SEC for interpreting subsection (iii) to allow the SEC only to increase, but not decrease that trigger).

174. See Proposed Regulation Crowdfunding, supra note 14, at 66,432 . ("Should we propose that the $\$ 1$ million limit be net of fees charged by the intermediary to host the offering on the intermediary's platform? Why or why not? If so, are there other fees that we should allow issuers to exclude when determining the amount to be raised and whether the issuer has reached the $\$ 1$ million limit?").

175. See id. at $66,430-32$.

176. Rule 502 requires "integration" of all sales that "are part of the same Regulation D offering" that are made less than six months before the start of a Regulation D offering or are made less than six months after completion of that offering. 17 C.F.R. 230.502(a) (2014). Therefore, for example, an issuer could not purport to host a separate Rule 505 offering in February and then a Rule 504 offering in July unless the two offerings combined comported with the rules of each and did not exceed the $\$ 1$ million offering cap in Rule 504. Id. If Section 4(6) offerings were integrated with Regulation D offerings in the same twelve month period, then any crowdfunded offering would be aggregated with those offerings and would have to meet the requirements of each of them. Id. 
the cost and complexity, one wonders why a crowdfunding issuer would do both instead of just the Regulation $D$ placement. That being said, one of the unintended consequences of that proposal, however, may be to allow general solicitation for a crowdfunding campaign offered simultaneously with a Rule 506 offering, described below. ${ }^{177}$

\section{The JOBS Act Enhances Other Capital-Raising Avenues}

The CROWDFUND Act was not a stand-alone piece of final legislation. Earlier bills proposed to legalize crowdfunding were the building blocks of the crowdfunding provisions in the larger JOBS Act, ${ }^{178}$ which was a push by various constituencies to encourage more IPOs, particularly IPOs among smaller issuers. The much-lauded rationale of the JOBS Act, particularly the provisions liberalizing rules to encourage smaller businesses to conduct IPOs, was to increase job creation. ${ }^{179}$

\section{The IPO On-Ramp}

To that end, the JOBS Act attempts to make the IPO process easier for smaller companies and to expand the usefulness of certain kinds of private placements. One of the major amendments to the IPO process was the creation of the much-discussed "on-ramp" for "emerging growth companies"("EGC"), ${ }^{180}$ which allows companies with less than $\$ 1$ billion in revenues to avoid some of the more onerous requirements of the IPO process $^{181}$ and its ongoing disclosure function for up to five years. ${ }^{182}$ To date, numerous companies have taken advantage of the ability to file registration documents confidentially ${ }^{183}$ and avoid certain disclosures; in fact,

177. See Bullard Testimony, supra note 170 , at 5 (warning that allowing a Section $4(6)$ crowdfunded offering within the same twelve months as a Rule 506 offering could change the nature of the crowdfunding statute by allowing general solicitation and attracting larger issuers that could dominate the market).

178. See Michael D. Guttentag, Protection from What? Investor Protection and the JOBS Act, 13 U.C. DAVIS BUS. L.J. 207, 234 (2013) (describing the JOBS Act as an "odd amalgam of different securities regulation provisions, brought together with little effort made at integration"); Hazen, supra note 144 , at $1750-53$ (detailing the earlier crowdfunding proposals as they led to the CROWDFUND Act).

179. See Guttentag, supra note 179 , at 243 (quoting the purpose of the JOBS Act to "increase American job creation and economic growth by improving access to the public capital markets for emerging growth companies").

180. JOBS Act, Pub. L. No. 112-106, 126 Stat. 306 (codified as amended at 15 U.S.C. $\$ 77$ b(a)(19) (2012)) (defining "emerging growth company").

181. Id. $\S 105$ (d) (allowing EGCs the unparalleled ability to solicit indications of interest from qualified institutional banks and accredited investors prior to filing a registration statement); id. $\S$ $77 \mathrm{f}(\mathrm{e})$ (allowing EGCs to file a registration statement on a confidential basis).

182. Several high profile companies have chosen to elect one or more of the opt-outs available to EGCs, including Twitter and GoPro. Twitter was able to file its Form S-1 registration statement confidentially and omit certain information from that registration statement. See Tomio Geron, Twitter Files for IPO-Confidentially, FORBES (Sept. 12, 2013, 5:11PM), http://www.forbes.com/sites/tomio geron/2013/09/12/twitter-files-for-ipo-confidentially/.

183. $\$ 77 \mathrm{f}(\mathrm{e})$. This section allows companies to file Form S-1 confidentially, with the document not being available on EDGAR. Id. Once the registration statement is declared effective, however, the documents are then publicly available. Id. This aspect of the IPO on-ramp allows companies to with- 
more companies have begun IPOs as EGCs than have not. ${ }^{184}$ The JOBS Act also increased the $\$ 5$ million offering limitation to $\$ 50$ million to make the rarely-used "mini-registration" process known as Regulation A more attractive. ${ }^{185}$

Neither of those changes competes directly with crowdfunding's Section 4(6) or is inherently inconsistent. Though the IPO on-ramp definitely liberalizes the process, it merely offers a disclosure discount coupon to issuers who were probably going to launch an expensive IPO regardless. Regulation A also entails more registration cost and complexity than Section 4(6).

\section{Rule 506 and General Solicitation}

Raising capital through a Regulation $\mathrm{D}$ exemption would be the traditional, legal alternative to illegal investor crowdfunding. The largest benefit legal crowdfunding would have over a Regulation $\mathrm{D}$ private placement would be that, under Rule 502, no offering under any of the Regulation D exemptions, Rules 504, 505, or 506, may be conducted with "general solicitation" of offerees. ${ }^{186}$ Therefore, underwriters or brokers must offer these securities only to offerees who have a preexisting relationship with the offeror or the issuer. Specifically, a private placement could never involve soliciting investments from strangers over the Internet. ${ }^{187}$ Title II ${ }^{188}$ of the JOBS Act, however, eliminated this restrictive limitation for Rule 506 private placements.

Effective September 23, 2013, offerings under Rule 506 may be conducted using general solicitation of any kind, as long as the issuer takes "reasonable steps" to ensure that all purchasers are accredited investors. ${ }^{189}$ Not to overstate the importance of lifting this ban, but general solicitation for private placements could be a sea change for capital raising outside of the IPO. ${ }^{190}$ Though the IPO is a "public offering," solicitation of prospective buyers prior to a registration statement being declared effective could not be called "general" or "public." All solicitation of prospective buyers must conform to the very detailed and limited rules

draw from registration without the public dissecting its registration materials should problems arise involving either the registration process or selling efforts. Id.

184. See David Gelles \& Michael J. de la Merced, "The New Normal" for Tech Companies and Others: The Stealth I.P.O., N.Y. TIMES, Feb. 9, 2014, at B1 (citing research by Renaissance Capital that seventy to eighty percent of companies that launched IPOs in 2013 did so as EGCs).

185. See $\S 77 \mathrm{c}(\mathrm{b})(2)(\mathrm{A})$; Coffee Testimony, supra note 144 (testifying that in 2010 , seven companies issued shares under Regulation $A)$.

186. See 17 C.F.R. $\$ 230.502$ (c) (2014).

187. See id. \$230.502(c)(1) (prohibiting "[a]ny advertisement, article, notice or other communication published in any newspaper, magazine, or similar media or broadcast over television or radio").

188. See JOBS Act, 15 U.S.C. \$ 201(a)(1) (2012).

189. See Eliminating the Prohibition Against General Solicitation and General Advertising in Rule 506 and Rule 144A Offerings, 77 Fed. Reg. 54,464, 54, 47-72 (proposed Sept. 5, 2012) (to be codified at 17 C.F.R. $\$ 230.506(c))$.

190. See Usha Rodrigues, SEC Releases Final Rule Allowing General Advertising for Certain Private Offerings, CONGLOMERATE (Jul. 11, 2013), http://www.theconglomerate.org/2013/07/sec-releasesfinal-rule-allowing-general-advertising-for-certain-private-offerings.html. 
of public offering registration: all "offers" must be accompanied by a written "prospectus"191 that conforms to Section 10 of the "33 Act, and any "written communication" constitutes a "prospectus." ${ }^{192}$ Furthermore, any "graphic communication," including an Internet website, constitutes a "written" communication. ${ }^{193}$ Prior to filing a registration statement, the issuer and others must not advertise the upcoming offering or otherwise "condition the market."194 Even during a public offering, issuers have to be careful about any written information, including information on their websites that mentions the offering. ${ }^{195}$ Even with the IPO reforms of 2005, nonreporting issuers are severely limited in how they interact with the public during registration. Accordingly, much of the selling effort takes place orally, either by telephone or face-to-face during road shows. Now, in a Rule 506 offering, an issuer could theoretically raise just as much money as in an IPO, albeit from accredited investors, and advertise on billboards, Super Bowl commercials, the Internet, Twitter, Facebook, or an airplane banner. ${ }^{196}$

Though the new Rule 506 may result in a decrease in IPOs, ${ }^{197}$ it surely will result in a decrease in interest in crowdfunding. ${ }^{198}$ While a publicly solicited Rule 506 offering may only involve accredited investors, the costs of such an offering may be substantially less for the issuer than a Section 4(6) crowdfunding campaign. The infrastructure waiting for crowdfunding, such as online platforms, can easily be used for accredited investor-only crowdfunding, without worries of violating the general solicitation ban. Or, a larger issuer could simultaneously launch a Rule 506 offering using general solicitation and a crowdfunding campaign, which will benefit from the free advertising. Unfortunately, this accredited investor-only crowdfunding future effectively eliminates one important promise of crowdfunding: the democratization of investing.

191. Securities Act of 1933,15 U.S.C. $§ 77 f(a)(2012)$.

192. Id. \& 77(b)(a)(10).

193. 17 C.F.R. $\$ 230.405$ (2014).

194. 15 U.S.C. $\$ 77 \mathrm{e}(\mathrm{c})$ (making it unlawful to offer to sell or offer to buy a security unless a registration statement has been filed); 17 C.F.R. $\S 230.163$ (A)(a) (creating safe harbor for statements by issuer that do not reference offering made 30 days or more before filing of the registration statement); id. $\S 230.135$ (a) (permitting the issuer to reference an offering without mentioning the underwriter or the price); id. $\$ 230.169$ (creating limited safe harbor for statements by issuer that are regular releases of factual business information).

195. The draconian nature of the so-called "gun-jumping" IPO rules were softened somewhat in 2005 as part of certain IPO reforms. Currently, Rule 433 allows for the use of "free writing prospectuses" by issuers during the registration period. 17 C.F.R. $\$ 230.433$. Non-reporting and unseasoned issuers, however, may only use free writing prospectuses if accompanied or preceded by the most recent preliminary prospectus. Id.

196. See Usha Rodrigues, In Search of Safe Harbor: Suggestions for the New Rule 506(c), 66 VAND. L. REV. EN BANC 29, 30 (2013).

197. IPOs have long been expensive and burdensome, but nevertheless remain a major step in the life cycle of larger companies. Theories explaining the staying power of IPOs include venture capital exit, founder diversification, liquidity, and increased capital raising power.

198. Jason W. Parsont, Crowdfunding: The Real and the Illusory Exemption, 4 HARv. Bus. L. REV. 281 (2014). 


\section{THE UNCERTAIN FUTURE OF INVESTOR CROWDFUNDING}

Unlike the euphoria surrounding equity crowdfunding prior to the enactment of the JOBS Act, and now the SEC proposed rules, currently the outlook for equity crowdfunding looks doubtful. Earlier concerns relating to fraud still remain, but now proponents of crowdfunding despair over the costly restrictions imposed on equity crowdfunding and portals. In addition, with the lifting of the ban on general solicitation for Rule 506 private placements, issuers may engage in "accredited crowdfunding"199 without a registered portal, under that exemption and not Section 4(6).

\section{A. Equity Crowdfunding Is Doomed Because Fraud Will Be Rampant}

A nonzero percentage of projects on websites like Kickstarter never deliver rewards or products to backers, ${ }^{200}$ generally for nonfraudulent reasons. ${ }^{201}$ A larger, but still small, percentage of member borrowers on Prosper and Lending Club default on their crowdfunded loans. ${ }^{202}$ Similarly, a substantial percentage of issuers that are crowdfunded will fail, with funders losing up to their full investment. The level of risk associated with investing in startup companies, which may be even greater than IPO issuers, is substantial. ${ }^{203}$ In addition, fraud on a crowdfunding portal is sure to happen, whether it is a full-fledged confidence scheme with a fake project and no plans to use the money for anything except lining pockets, ${ }^{204}$ or it is a legitimate project with issuers that make falsely glowing

199. See id. at 1 .

200. See Mollick, Dynamics, supra note 90 , at 13 (showing results that "the vast majority" of successfully funded Kickstarter projects eventually deliver a project, but seventy-five percent are delayed).

201. In April 2014, however, the State of Washington filed a lawsuit under the Washington Consumer Protection Act against Altius Management LLC and its president, Edward J. Polchlopek III, for unfair and deceptive trade practices. Complaint at 4, Washington v. Altius Mgmt., LLC, No. 14-2. 12425 (Wash. Superior Ct. Apr. 30, 2014). According to the Complaint, Altius Management created a Kickstarter project for "Asylum Playing Cards," which attracted $\$ 25,146$ from 810 backers, more than meeting its $\$ 15,000$ goal. Id. at 2-5. Delivery of playing cards to backers was promised by December 2012. Id. at 5. As of April 2014, however, no backer had received anything and no information was forthcoming. Id. The penalty for violating the Act is $\$ 2000$ per thirty-one violations against residents of Washington. Id. at 7. See also, Niraj Chokshi, The First State Lawsuit Over a Crowdfunding Project is About a Deck of Cards, WASH. POST GOVBEAT BLOG (May 2, 2014), http://www.washingtonpost .com/blogs/govbeat/wp/2014/05/02/the-first-state-lawsuit-over-a-crowdfunding-project-is-about-a-deckof-cards/.

202. See Prosper Funding LLC, Registration Statement (Amendment No. 8 to Form S-1) 13 (Dec. 21,2012 ) (disclosing that out of 34,042 loans that were made by Prosper between July 13, 2009 and September $30,2012,2 \%$ were between one and thirty days late; $2.1 \%$ were over thirty days late; and $6.1 \%$ had defaulted).

203. See Bullard Testimony, supra note 170, at 24 ("Small business failures are not typically the result of fraud. They are business failures that result from incompetence and/or inexperience. This means that, no matter what disclosures are provided, sophistication tests are applied, or intermediary rules are adopted, about half of crowdfunding investments in crowdfunded startups may be a total loss.").

204. See Coffee Testimony, supra note 144 (detailing a scenario in which con artists could set up online solicitations for "phantom" projects). 
statements about the business to attract funders. ${ }^{205}$ There is good reason to think that phony crowdfunding solicitations on a legitimate internet portal will attract more investors than face-to-face solicitations. More importantly, "leaving town" with fools' money is easier when there is no town.

On the other hand, the public Internet face of crowdfunding leads some to believe that fraud will be ferreted about by the crowd and thus both caught and deterred. ${ }^{206}$ The transparency and centralized nature of crowdfunding portals will make fraud harder rather than easier. ${ }^{207} \mathrm{Ac}$ cording to congressional testimony, no fraud to date has been reported by Prosper or U.K. crowdlending sites. ${ }^{208}$

Critics of crowdfunding were not comforted by the CROWDFUND Act or the proposed regulations because of the paucity of provisions aimed at combatting fraud. Section $4(6)$ (c) does, though, provide for liability for both issuers and the portal. Theoretically, the requirement that retail equity crowdfunding take place on a registered portal subject to liability will force the portal to take on a gatekeeping role similar to an underwriter in both private placements and IPOs. ${ }^{209}$ This additional burden on portals, which prior to the CROWDFUND Act seemed more like passive sites like eBay or Craigslist, leads to other, more negative predictions.

\section{B. Equity Crowdfunding Is Doomed Because Section 4(6) Is Too Costly and Burdensome on Issuers and Portals}

No one disagrees that the resulting crowdfunding exemption in Section 4(6) will be burdensome on both issuers and portals. ${ }^{210}$ Project spon-

205. See Venkat Kuppuswamy \& Barry L. Bayus, Crowdfunding Creative Ideas: The Dynamics of Project Backers in Kickstarter 26 (Univ. Of N.C. Kenan-Flager Research Paper No. 2013-15, 2014), available at http:/www.ssrn.com/abstract $=2234765$ (arguing that irrational herding behavior will increase the chances for fraud in crowdfunding).

206. See Rowe Testimony, supra note 9, at 2 (comparing the review mechanism of eBay.com to the potential of crowdfunders to exchange information about fraudsters).

207. See RocketHub Testimony, supra note 171, at 2 ("Every securities market and/or offering has the potential for fraud, but crowdfunding structures help minimize that risk. Crowdfunding is highly transparent, and there is substantial feedback from other community participants. The crowd helps police players and keeps them honest. Portals provide a clear and central location for communication by potential investors to analyze and share their views on offerings. The web based structure also allows portals and regulators to provide risk disclosure and investor education. In addition, we expect portal operators will undertake a gatekeeping role in authenticating issuer identity and requiring minimum standards for issuers.").

208. See id.

209. Various commenters suggested that portals would be in the best position to vet crowdfunding issuers for fraud, though they may not have encouraged both registration and liability. See Rowe Testimony, supra note 9, at 3 (suggesting that portals compete for reputation in vetting enterprises but not be burdened with excessive liability); Lynn Testimony, supra note 142, at 4 (recommending that portals have some "stamp of approval" but not be overburdened with regulation so as to make running a portal uneconomic).

210. See Thompson \& Langevoort, supra note 150, at 1605-06 ("[T]his will not turn out to be particularly fertile ground for start-up capital-raising activity; the regulatory costs are likely to take too much of the small amounts of money that can be raised even if portals absorb some of the anticipated costs."). 
sors will have to incorporate, create entity tax returns and financial statements, and have those financial statements audited if the target amount is greater than $\$ 500,000 .^{211}$ The economies of scale will not be there for most issuers. ${ }^{212}$ In addition, portals will not be passive bulletin boards but will be required to do due diligence and face liability for fraudulent misstatements and omissions from crowdfunding issuers. To compensate for this type of liability, portals will have to charge crowdfunders higher fees for listing, increasing costs for issuers. Given the small size of the issues, issuers may not be willing to pay exorbitant listing fees. In addition, portals would necessarily have to limit the number of offerors. In 2012, 18,109 projects on Kickstarter were successful, suggesting approximately 36,000 projects were offered in that year alone..$^{213}$ To do any type of due diligence, a site as large as Kickstarter would necessarily have a staff of hundreds.

In addition, portals are tasked with ensuring the investors do not exceed aggregate investing limits in a twelve-month period for all Section $4(6)$ offerings participated in by a single investor. In 2013, Kickstarter boasted that over three million individuals backed successful projects. ${ }^{214}$ For a portal to be responsible for even minimum certification of over three million individuals a year, from 214 countries and territories, is almost inconceivable. ${ }^{215}$

Though few alternatives exist to create economies of scale for issuers, established investment banks could create retail crowdfunding portals within their existing businesses. At first, investment banks explored creating online auction IPO platforms, but may have realized that offering that service would reduce demand for their more lucrative bookbuilding IPO services. Investment banks still might see crowdfunding as a way to establish relationships with promising issuers, who may later want private placement or IPO services. If seen this way, a crowdfunding portal might be a loss leader or might be somewhat subsidized by other financial services. This would hold true, though, only if the financial firms

211. The hierarchy of financial disclosure found in Section $4 A(b)(1)(D)$ may have (at least) two unintended consequences. First, crowdfunding issuers may cluster at the $\$ 500,000$ target and below, opting out of the additional costs for audited financials at the risk of not raising sufficient capital. See Alan R. Palmiter, Pricing Disclosure: Crowdfunding's Curious Conundrum, 7 OHIO ST. ENTREPEN. BUS. L. J. 373, 375 (2012). Second, issuers may strategically set low targets because audited financials are not needed if the actual amount raised is above $\$ 500,000$ and greater than the lower target. Id. In addition, two crowdfunding offerings twelve months apart for $\$ 500,000$ would not trigger the need for audited statements. Id.

212. See Robb Mandelbaum, What the Proposed Crowdfunding Rules Could Cost Businesses, N.Y. TIMES YOU'RE THE BOSS BLOG (Nov. 14, 2013, 7:00AM), http://boss.blogs.nytimes.com/2013/11/ 14/what-the-proposed-crowdfunding-rules-could-cost-businesses/?_php=true \&_type=blogs \&_r=0 (calculating that the combined costs for crowdfunding exceed the cost of a small business owner using a credit card).

213. The Best of 2012, KICKSTARTER, https:/www.kickstarter.com/year/2012?ref=footer\#overall _pledged (last visited Oct. 20, 2014).

214. 2013: The Year in Kickstarter, KICKSTARTER, https:/www.kickstarter.com/year/2013/?ref =footer\#1-people-dollars (last visited Oct. 20, 2014).

215. See Princess BRIDE (Act III Communications 1987) ("You keep using that word. I do not think it means what you think it means."). 
believed that promising young companies were launching retail equity crowdfunded offerings.

\section{Equity Crowdfunding Is Doomed Because It Will Be a Market of Lemons}

Perhaps because of the outsized costs, or the availability of other exemptions discussed below, commentators have suggested that promising companies may steer clear of crowdfunding. ${ }^{216}$ Then, the landscape would be filled with companies that were not able to secure other earlystage funding. ${ }^{217}$ The end result would be that crowdfunding would be a signal, whether true or not, ${ }^{218}$ of poor quality. Though some high quality projects might choose to have a crowdfunding offering for various reasons, retail investors might be frightened away, unable to distinguish between good and bad offerings. ${ }^{219}$ In addition, if there is fraud, or if there is a sense that fraud is prevalent, then even good offerings will be tainted by the possibility of fraud.

If the retail equity crowdfunding landscape does begin to resemble a market for lemons, then issuers could take steps to signal quality. Thirdparty certification might be one avenue, but such certification would be costly. For example, quality issuers might choose to provide audited financials regardless of target capital raise amounts. ${ }^{220}$ Some have suggested that angel investors or VC firms might tell prospects to try a crowdfunding offering to "test the waters." 221 Perhaps those third parties could make a token investment or some other commitment so that crowdfunding issuers could present themselves as having funding from a brandname VC firm.

216. See The JOBS Act: Importance of Prompt Implementation for Entrepreneurs, Capital Formation, and Job Creation. Joint Hearing Before the Subcomm. on TARP, Fin. Servs., \& Bailouts of Pub. \& Private Programs of the H. Comm. on Oversight \& Gov't Reform \& the Subcomm. on Capital Mkts. \& Gov't Sponsored Enter. of the H. Comm. on Fin. Servs. 112th Cong. 2 (Sept. 13, 2012) (statement of Naval Ravikant, CEO, AngelList) (predicting that if crowdfunding regulations are too restrictive, then startups who can get funding elsewhere will, leaving the crowdfunding space for the "desperate").

217. See Dorff, supra note 156 , at 26 (hypothesizing that crowdfunding will be for companies that can't get angel financing and will suffer from not getting the benefits angels provide).

218. Id. at 33 ("Having fewer quality prospects to choose from will only increase the already high odds that crowdfunders will lose their investments.").

219. See George A. Akerlof, The Market for "Lemons": Quality Uncertainty and the Market Mechanisms, 84 Q. J. ECON. 488, 489 (1970) (describing this phenomenon using the used car market as an example).

220. See Proposed Regulation Crowdfunding, supra note 14, at 66,554 (Instruction 10) (allowing issuers to provide audited financial statements even if the aggregate amount raised is less than $\$ 500,000)$.

221. See Claire Ingram et al., Solving the Puzzle of Crowdfunding: Where Technological Affordances and Institutional Entrepreneurship Collide 1, 7 (Social Science Research Network, Working Paper 2285426, 2013), available at http://www.ssrn.com/abstract=2285426. 


\section{Retail Equity Crowdfunding Is Doomed Because Issuers Will Choose Accredited Equity Crowdfunding under New Rule 506}

Commentators predict that accredited crowdfunding under Rule 506 will eclipse retail crowdfunding and make the latter merely a back-up plan for hard-to-fund issuers. ${ }^{222}$ Websites already exist among angel investors that can be expanded to add general solicitation to other accredited investor prospects, such as AngelList ${ }^{223}$, CircleUp, ${ }^{224}$ Portfolia, ${ }^{225}$ FundersClub ${ }^{226}$ MicroVentures, ${ }^{227}$ and Fundrise, ${ }^{228}$ and others are sure to follow. Unlike retail crowdfunding under Section 4(6), portals will not need to meet the requirements of Section $4 \mathrm{~A}(\mathrm{a}),{ }^{229}$ and issuers will not have to provide mandatory disclosure under Section 4A(b). Finally, issuers can raise more than $\$ 1$ million, and do not have to set or meet a target amount as in Section $4 A(a)(7) .{ }^{230}$

\section{E. Retail Equity Crowdfunding Is Doomed Because Funders Will Not Participate in Future Profits}

One stated criticism of crowdfunding is that crowdfunded firms will not be able to obtain later financing through traditional channels. Then, funders will not have an exit mechanism because there will be no IPO or acquisition. Inability to raise later capital could be a result of crowdfunding stigma ${ }^{231}$ or unwillingness of $\mathrm{VC}$ firms to invest in a firm with thousands of shareholders. ${ }^{232}$

An opposite criticism of crowdfunding is that if there is later financing, crowdfunders will not participate in that potential upside. New rounds of financing will almost certainly dilute crowdfunders, ${ }^{233}$ with only

222. See Parsont, supra note 199, at 5 (claiming "that accredited crowdfunding is likely to dominate and, depending on SEC action, could render retail crowdfunding superfluous or a market for lemons").

223. ANGELLIST, http://angel.co (last visited Oct. 20, 2014).

224. CIRCLEUP, http://circleup.com (last visited Oct. 20, 2014).

225. PORTFOLIA, http://portfolia.com (last visited Oct. 20, 2014).

226. FUNDERS CLUB, http://www.fundersclub.com (last visited Oct. 20, 2014).

227. MICROVENTURES, http://www.microventures.com (last visited Oct. 20, 2014).

228. FUNDRISE, http://www.fundrise.com (last visited Oct. 20, 2014).

229. These portals may have to register as broker-dealers, however, unless they comply with Section 4(b) of the Securities Act, which requires the platform to receive no compensation. Securities Act of 1933,15 U.S.C. $\$ 77 \mathrm{~d}(\mathrm{~b})(1)$ (2012). AngelList currently displays a 2012 legal opinion from K\&L Gates on its site to the effect that it is exempt from broker-dealer registration under Section 4(b), added by the JOBS Act. See Letter from K\&L Gates to AngelList (Aug. 30, 2012) available at https: //angel.co/documents/AngelList\%20Legal\%20Opinion \%20-\%20Aug \%2030\%202012.pdf.

230. See id. $\$ 77 \mathrm{~d}-1$ (requiring portals and brokers to "ensure that all offering proceeds are only provided to the issuer when the aggregate capital raised from all investors is equal to or greater than a target offering amount").

231. See Coffee Testimony, supra note 144 , at 3.

232. The CROWDFUND Act allows crowdfunding issuers to avoid the two thousand shareholder rule (previously the five hundred shareholder rule) that triggers registration under the Securities Act. See Donald C. Langevoort \& Robert B. Thompson, "Publicness" in Contemporary Security Regulation After the JOBS Act, 101 GEO. L.J. 337, 354 (2013). VC firms may be unexcited about the "equity overhang."

233. See Lynn Testimony, supra note 142, at 5 (suggesting a standard subscription agreement required by portals to ensure that crowdfunders are not diluted or otherwise denied participation in fu- 
later investors enjoying any profits from an exit event. Alternatively, venture finance companies will repurchase crowdfunded securities during a later round of financing, which may occur before those shares have appreciated. ${ }^{234}$

An assumption behind this argument is that equity crowdfunders are primarily interested in outsized returns. So, the argument goes, when crowdfunders are bought out by venture capital funds a year or two before a big IPO or acquisition, and they learn of the great returns that they missed, the crowd will abandon crowdfunding. Crowdfunders, however, may have different motivations than traditional angel investors and IPO investors. For example, many of the projects funded on Kickstarter have commercial value, such as books, documentaries, movies, and music. Funders understand that should these projects become blockbusters or bestsellers that they will receive merely what they were promised: a DVD, an advance copy, a liner note. This reality does not seem to slow down donor crowdfunding.

\section{F. Retail Equity Crowdfunding Is Doomed Because the Financial Services Industry Will Avoid Crowdfunded Startups}

In a perfect world, a crowdfunded offering would become part of the life cycle of a startup company: friends and family funding, crowdfunding, angel investing, venture capital investing, initial public offering. However, equity crowdfunding may not supplant venture capital investing for two of the same reasons that auction IPOs did not threaten the bookbuilding IPO.

First, just as underwriters add value to IPOs by creating demand for the offering among their demand networks, venture capital firms bring more than financial capital to founders. Venture capital firms bring managerial expertise, networks, and industry knowledge that the crowd may not be able to provide. Some debate exists as to what nonmonetary benefits can be extracted from the crowd. One theory is that equity crowdfunding markets could flourish as information markets, providing costly and important information to issuers. Particularly for projects that are consumer products, the crowd could be a very helpful test market. Retail investors are consumers and may have as a group as much or more market expertise than a VC firm. Crowdfunders who flock to a particular consumer product project are contributing information that they see the product as valuable and that they predict that others will also. Crowd-

ture upside); John S. (Jack) Wroldsen, The Social Network and the CROWDFUND Act: Zuckerberg, Saverin, and Venture Capital's Dilution of the Crowd, 15 VAND. J. ENT. \& TECH. L. 583 (2013) (suggesting that contractual rights could protect crowdfunders against future dilution).

234. See Angel Testimony, supra note 13, at 12 (explaining that the exit for the crowdfunder will be either another round of financing or an acquisition event). 
funding issuers could find other ways to fine-tune that contribution to give feedback on price and other aspects of the product. ${ }^{235}$

Another pro-crowdfunding theory is that crowdfunders act as evangelists in ways that a VC firm cannot. One thousand crowdfunders will be able to provide word of mouth advertising through social networks to more consumers than one VC firm.

A related criticism is that one powerful value that $\mathrm{VC}$ firms bring is selection ability. VC-funded firms are able to signal to the market at IPO that they have great potential due to the sorting expertise of VC firms. The accuracy of VC firms' selection ability, however, has been the subject of debate ${ }^{236}$ and many academic studies. ${ }^{237}$ The counterpoint to this argument is obvious: the crowd may be able to select promising projects with as much expertise, given VC firms' low success rate. As commentators point out, VCs are able to profit in the long term through diversification across many different investments. Crowdfunders are not able to do that given the aggregate limits under Section 4(6)..$^{238}$

Second, equity crowdfunding may fail just as the online auction IPO failed because a crowdfunded issuer may find that a Section 4(6) offering forecloses other traditional avenues of early stage funding. One concern is that crowdfunding would carry a stigma and send a signal that the project could not successfully get funded elsewhere. In the auction IPO, traditional Wall Street players may shun auction issuers by financial firms not providing analyst coverage and by institutional investors not purchasing equity shares. These two actions can depress the issuer's stock and cause the issuer to lose value. If time proves that crowdfunded issuers are not able to tap into traditional sources of funding later, then crowdfunding will not prosper. First, issuers will not be able to scale up if they can only raise $\$ 1$ million every twelve months in crowdfunding and not get larger infusions from private equity firms. Second, retail investors in forprofit companies eventually want a return on their investment, which traditionally comes through some sort of exit mechanism, either an acquisition by another firm or an IPO. ${ }^{239}$ If the next few years do not have

235. See Thompson \& Langevoort, supra note 150, at 1606 (regretting that nothing in the CROWDFUND Act mandated or provided for information gathering from crowdfunders). In the proposed regulations, however, certain safe harbors indicate that the SEC envisions allowing, but not mandating, issuers to have interaction via the portal with crowdfunders during the offering. See Proposed Regulation Crowdfunding, supra note 14, at 66,445.

236. See Davidoff, Trepidation, supra note 172 (stating that forty percent of VC investments fail, forty percent break even, and twenty percent have a "decent to high return"); Dorff, supra note 156, at 20 (stating that seventy-five percent of positive returns to angel investors come from ten percent of projects, so on average, crowdfunding will be a losing proposition).

237. See generally Mollick, Selection, supra note 35 (reviewing the economics literature on VC selection ability).

238. See Securities Act of 1933, 15 U.S.C. \& 77d-1(a)(8) (2012) (requiring portals and brokers to "make such efforts as the Commission determines appropriate, by rule, to ensure that no investor in a 12-month period has purchased securities offered pursuant to section $4(6)$ that, in the aggregate, from all issuers, exceed the investment limits set forth in section 4(6)(B)").

239. See Gerrit K.C. Ahlers et al., Signaling in Equity Crowdfunding (Social Sciences Research Network, Working Paper No. 2161587, 2012), available at http://ssrn.com/abstract $=2161587$ (analyzing equity crowdfunding projects from non-U.S. platforms and concluding that "start-ups that signal their 
stories of crowdfunded issuers being acquired at a profit or launching IPOs, then investor demand for crowdfunding may dwindle.

Finally, should accredited crowdfunding flourish under Rule 506, this success would not be a win for proponents of retail crowdfunding. One of the grand promises of equity crowdfunding was that it would democratize early stage investing. Accredited crowdfunding by definition does not accomplish that goal.

\section{EQUITY CROWDFUNDING FOR SOCIAL ENTERPRISE}

Given the uncertainties about equity crowdfunding-cost, stigma, dilution, signaling - the benefits of crowdfunding for most for-profit companies seem small, if not negative. Yet, current crowdfunding trends could inform which types of companies will continue to flourish by raising funds on the Internet. Prior to the passage of the crowdfunding regulations, many commercial projects enjoyed the fruits of online crowdfunding even thought they could not legally offer equity participations in a for-profit enterprise with plenty of future growth. Currently, charitable, altruistic, and artistic crowdfunding dominates a large crowdfunding space, not would-be equity issuances. Of the tens of thousands of projects funded through portals in the United States today, most of them are projects that could be commercial but are prosocial ventures funded by mere donations. According to Kickstarter, projects with the highest success rates are "Dance," "Theater," and "Music." 240 In fact, these are the only projects with success rates over fifty percent. The next two are "Comics" and "Art."241 By volume, the greatest number of successful projects are in the following categories: "Music," "Film \& Video," "Art," "Publishing," and "Theater."242 These projects are generally projects that could provide profits, though small profits on average, for the entrepreneur who sells the song, album, film, photograph, painting, book, or tickets to a live performance. Funders, though, are quite willing to give money without expectation of return or even a tax deduction. Funders are promised token gifts, which range from small units of the artists' work to acknowledgements to "eternal gratitude." ${ }^{243}$ Funders seem to be attracted to these projects because of the social good that art, and even comics and video games, create for the world at large. Even though the creator is retaining the proceeds and profits, if any, funders seem inclined to invest, even without an expected return.

\footnotetext{
intention to seek an exit by either IPO or a trade sale are more likely to attract investors than those planning to use other forms of exit").

240. See Stats, KICKSTARTER, https://www.kickstarter.com/help/stats?ref=footer (last visited Feb. 14,2013 ) (showing the success rate for music as $55.18 \%$; theater as $64.34 \%$; and dance as $70.37 \%$ ).

241. See id. (showing the success rate for comics as $49.32 \%$ and art as $47.91 \%$ ).

242. See id. (reporting 15,049 successful music projects; 13,132 film and video projects; 5626 art projects; 5139 publishing projects, and 3565 theater projects).

243. Pattern Store by Indianapolis Fashion Collective, KICKSTARTER, https://www.kickstarter.com/ projects/181687873/pattern-store/comments?cursor=0\&direction=asc (last visited Oct. 20, 2014).
} 
This remains true for even more commercial projects. Some projects, like the now famous Pebble watch ${ }^{244}$ and Veronica Mars Movie, ${ }^{245}$ are arguably commercial projects with limited prosocial aspects for which a large return may be available. Some funders may truly be interested in contributing only with a commitment to receive the product early in return, but they are definitely taking a risk that the product will not be produced at all. In the United States particularly, investors may merely be attracted by a great idea and may use small amounts of money as votes for supporting an environment conducive to both this great idea and more great ideas. Some of the entrepreneurs are not even the "little guy," but the idea of giving even known funders, like Zach Braff and James Franco, the freedom and creative space to work attracts money from the crowd. ${ }^{246}$

Moreover, Kiva backers fund six thousand loans a week, ${ }^{247}$ without any expectation of interest as compensation for the use of that money and no recourse should the principal not be repaid. In fact, no-interest lenders do not receive a tax deduction on either the principal or the foregone interest. ${ }^{248}$ In addition, many of those lenders continually reloan principal that has been repaid. ${ }^{249}$ Since its launch in 2005 , Kiva has funded over $\$ 1.3$ million from funds loaned free from strangers who support the cause of microfinance. ${ }^{250}$

Given the appetite of funders for substantively attractive projects that offer little or no return, the crowdfunding winners following the passage of Section 4(2) seems to be in the niche of social enterprise: forprofit entities involved in prosocial projects. These low-profit projects with strong corporate missions could legally attract equity crowdfunding from the general public, who may not be concerned with high returns, ex-

244. Fell, supra note 89.

245. Sarah Rappaport, Kickstarter Funding Brings 'Veronica Mars' Movie to Life, CNBC (Mar. 12, 2014), http://www.cnbc.com/id/1014867\#.

246. Kickstarter boasts many feature films that have been crowdfunded, claiming ten percent of films at Sundance in 2013 were crowdfunded. Courtney Garcia, Kickstarter Co-Founder Defends Spike Lee and His New Model for Moviemaking, THE GRIO (Aug. 12, 2013), http://thegrio.com/ 2013/08/12/kickstarter-founder-defends-spike-lee-and-his-new-model-for-moviemaking/. These films compete with films that are investor-funded. Kickstarter backers have backed movie projects that did not attract investor funding, such as the Veronica Mars movie and Zach Braff's movie, Wish I Was Here. See supra note 84 . James Franco, after criticizing Braff for using Kickstarter, later used Indiegogo to crowdfund a movie adaptation of a book of stories he authored, entitled Palo Alto Stories. His campaign, though, fell short of his five hundred thousand dollar funding goal. See Palo Alto Stories by James Franco, INDIEGOGO, http://www.indiegogo.com/projects/palo-alto-stories-by-james-franco (last visited Oct. 20, 2014). Screenwriter Charlie Kaufman, whose movies Adaptation and Synecdoche, New York were more critical than commercial successes, launched a successful campaign to crowdfund an animated movie, Anomalisa. See Anita Hamilton, 5 Buzziest Movies to Get Crowdfunded, TIME (Apr. 25, 2013), http://business.time.com/2013/04/25/5-buzziest-movies-to-get-crowdfunded/.

Crowdfunders, however, may change their minds about their favorite misunderstood artists should these highly anticipated crowdfunded movies have successful box office returns.

247. See Statistics, KIVA, http://www.kiva.org/about/stats (last visited Oct. 20, 2014).

248. See Lawsky, supra note 91 , at 1534.

249. See How Kiva Works, KIVA, http://www.kiva.org/about/how (last visited Oct. 20, 2014) (numbering the four steps lenders take as (1) "Make a Loan;" (2) "Get Updates;" (3) "Get Paid Back;" and (4) "Repeat").

250. Statistics, KIVA.ORG, http://www.kiva.org/about/stats (last visited Oct. 20, 2014). 
it strategies, or late round dilution. In addition, social entrepreneurs may not be concerned with attracting later rounds of funding from VC firms, where the prospect of mission drift looms large. ${ }^{251}$ In fact, crowdfunding may create branding opportunities for prosocial ventures.

For for-profit corporations that attempt to serve a "double line," outside funding from private sources or the public at large threaten to erode an ethos inconsistent with maximizing shareholder value. Though many regulatory proposals have attempted to carve out space for social enterprise through corporate governance, corporate finance may offer more potential. New organizational forms such as the benefit corporation and low-profit limited liability companies seek to protect shareholders from the corporation that is tempted (perhaps by different shareholders) to drift away from its mission. ${ }^{252}$ Danger may be drawn from both concentrated owners, such as venture capital funds and angel investors, and the general public who are merely looking for a positive return. Crowdfunding may serve to insulate the corporation from shareholders who do not believe in the mission and are looking for either high returns or a liquid investment.

Finally, crowdfunding might be less of a stigma for a social enterprise, which might use its populist quality for branding purposes. In addition, social enterprise firms may not wish to have later rounds of funding and an eventual IPO, which might be forestalled by a crowdfunding offering.

Websites already exist to crowdfund nonprofit social entrepreneurship, like Razoo ${ }^{253}$ and StartSomeGood, ${ }^{254}$ and other sites are poised to launch equity crowdfunding in social enterprises, like Impact Trader. ${ }^{255}$ Furthermore, though the increased liability and obligations imposed on portals by Section $4 \mathrm{~A}$ may create disincentives for portals to be established and operate, not-for-profit portals could be created to support social entrepreneurship.

\section{CONCLUSION}

The CROWDFUND Act and its enabling regulation were anxiously awaited by a market eager to raise funds and invest in crowdfunded enterprises. As it turned out, the long overdue exemption for securities registration seems more likely to choke out quality equity crowdfunding than support it. Not only do the requirements of Section 4(6) burden issuers and portal intermediaries with costly disclosure and certification

251. See generally PhIL VisCher, ME, Myself AND Bob: A TRUe Story ABOUT DREAMs, God, and TALKING Vegetables (2006) (detailing the rise and fall of Big Idea Productions, and how the creator of Veggie Tales lost creative control of the faith-based company after accepting outside funding and the management changes that came with it, leading to the bankruptcy of that company).

252. See Dana Brakman Reiser, Theorizing Forms for Social Enterprise, 62 EMORY L.J. 681, 68991 (2013).

253. RAZOO, www.razoo.com (last visited Oct. 20, 2014).

254. STARTSOMEGOOD, www.startsomegood.com (last visited Oct. 20, 2014).

255. IMPACT TRADER, www.impacttrader.com (last visited Oct. 20, 2014). 
requirements, but it also subjects them to antifraud provisions of Section 12 and $17 .{ }^{256}$ Due to the possibility of fraud, the crowdfunding market may become a "market of lemons" for issuers unable to obtain other early-stage financing. In addition, liberalization of other registration exemptions will channel quality projects from "retail crowdfunding" under Section 4(6) to "accredited crowdfunding" under Rule 506 of Regulation D.

Though crowdfunding has the promise of disintermediating earlystage financing and democratizing both access to capital and access to investment opportunities, a shift from retail crowdfunding to accredited crowdfunding will not fulfill that promise. Just as democratic online auction IPOs did not supplant traditional bookbuilding IPOs, crowdfunding may not survive a backlash from angel investors and VC firms.

Even so, social entrepreneurs may benefit from crowdfunding. Because low-profit social entrepreneurs really are looking for a Kickstarterplus offering, not a Merrill-minus offering, they can harness the willingness of the crowd to fund prosocial and artistic endeavors with little expectation of return or a tax deduction. This type of corporate finance revolution may prove more lasting than corporate governance experiments such as benefit corporations.

256. Heminway \& Hoffman, Peril, supra note 132, at 908. 
